\title{
The FOMC in 1980: A Year of Reserve Targeting
}

\author{
R. ALTON GILBERT and MICHAEL E. TREBING
}

$\mathrm{O}$ N October 6, 1979, the Federal Reserve announced the beginning of a new approach to the implementation of monetary policy: it would attempt to achieve better control of the growth of the monetary aggregates by "placing greater emphasis in day-to-day operations on the supply of bank reserves and less emphasis on confining short-term fluctuations in the federal funds rate." 1 A reason for adopting such a strategy was to "assure better control over the expansion of money and bank credit." The 1980 calendar year was the first full year of monetary policy under the new procedure of reserve targeting.

The year was a turbulent one for the economy and for the conduct of monetary policy. Interest rates fluctuated more than during past years, an outcome that was anticipated when the reserve targeting strategy was adopted. The growth rates of the monetary aggregates, however, were also highly variable during 1980 , even though the new procedure for implementing monetary policy was intended to promote better monetary control. A brief period of credit controls contributed to turbulence in the economy and the conduct of monetary policy, by reducing demand for credit by more than anticipated by the Federal Reserve when the controls were imposed.

The conduct of monetary policy was also affected by unusual developments during the year. The Depository Institutions Deregulation and Monetary Control Act of 1980 altered the institutional environment in which monetary policy is implemented. In addition,

Note: Citations referred to as "Record" are to the "Record of Palieg Actions of the Federal Open Market Committee" found in varions issues of the Federal Reserte Btalletin.

1"Announcements: Monetary Policy Actions," Federal Reserve Bulletin (October 1979 ), p. 830 .

zibid. the Federal Open Market Committee (Committee) specified its objectives in terms of new measures of the monetary aggregates, which were released in February 1980.

This article discusses the monetary policy decisions of the Committee during 1980. The Committee specifies its objectives for each calendar year in terms of ranges of growth rates for several monetary aggregates. Policies to be implemented between meetings are stated in terms of growth rates for the monetary aggregates and ranges for the federal funds rate.

Growth rates of the monetary aggregates over 1980 are compared with the announced target ranges for the year to determine how successfully the Federal Reserve controlled money growth on an annual basis, Next, the pattern of money growth during the year is compared with the short-term objectives of the Committee. Finally, the current procedure for implementing monetary policy is described and policy actions analyzed to determine the factors that ac counted for the patterr of money growth over the year.

\section{NEW MEASURES OF MONETARY AGGREGATES}

In response to significant financial innovations in recent years, the Board of Governors announced new definitions of the monetary aggregates in February. ${ }^{3}$ The Committee specified its 1980 objectives for money growth in terms of these new monetary aggregates: M1A, M1B, M2, M3 and commercial bank credit.

"For a desciption of the new aggregates, ses thomas 1 . Simpson, "The Redefined Monetary Ageredotes," Federal Reserve

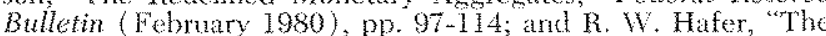
New Monetary Agregates" this Review (Febrary 1980), pp. 25-32. 


\section{Organization of the Committee in 1980}

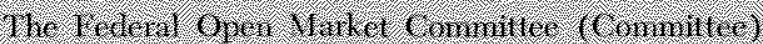

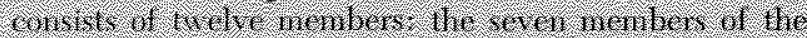

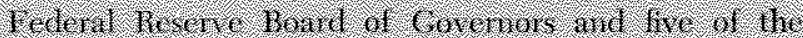

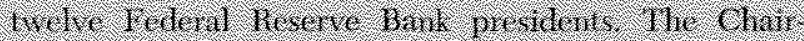

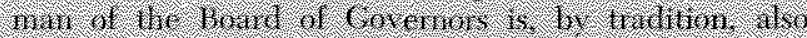

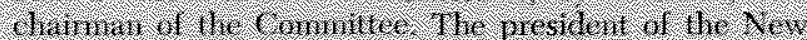

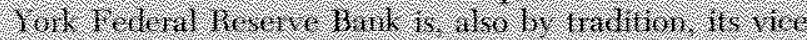

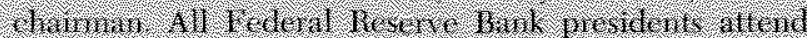

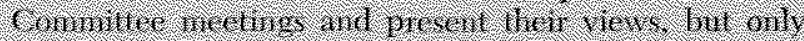

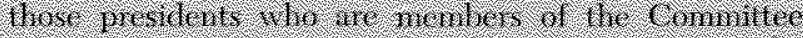

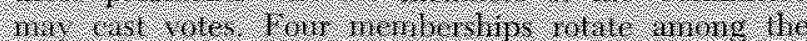

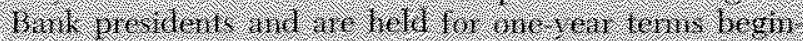

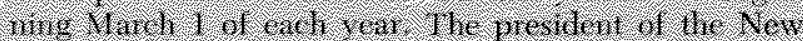

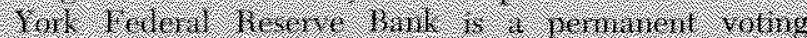

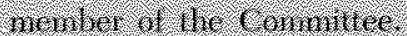

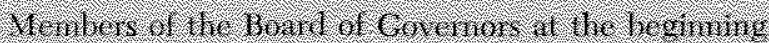

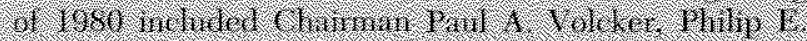

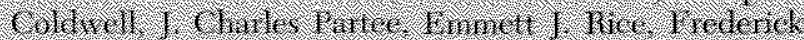

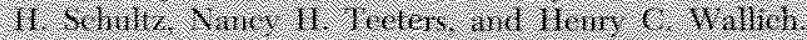

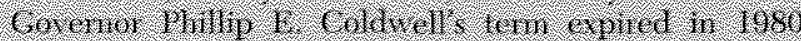

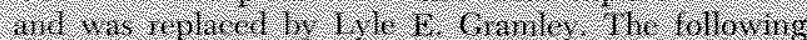

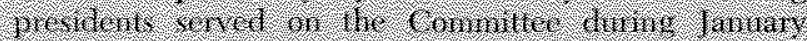

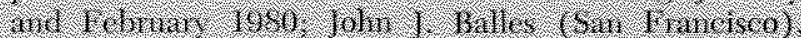

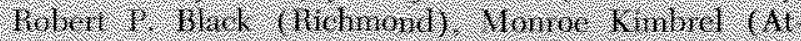

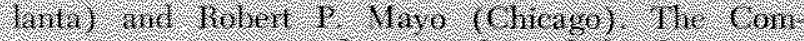

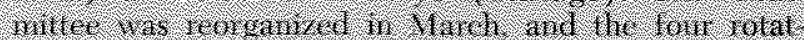

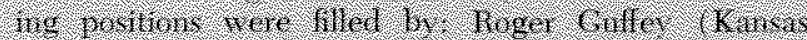

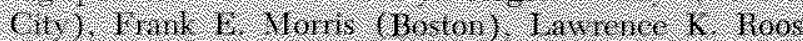

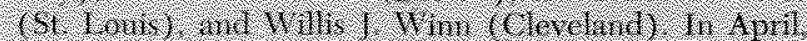

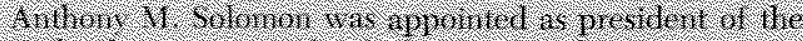

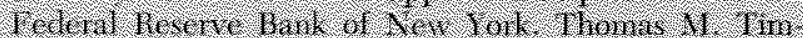

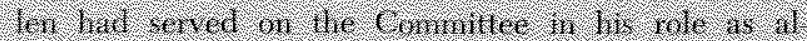

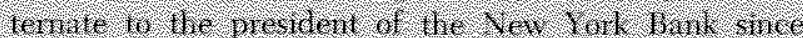

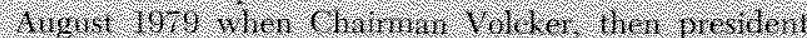

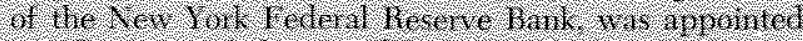

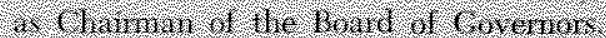

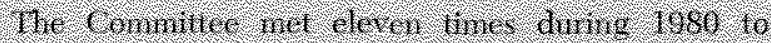

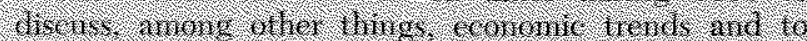

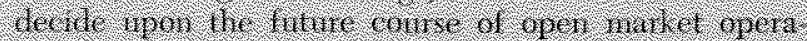

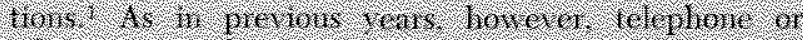

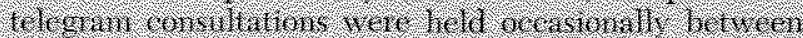

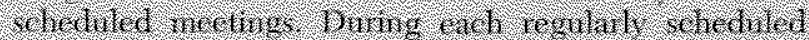

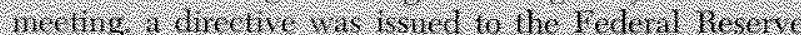

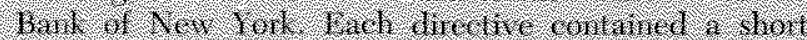

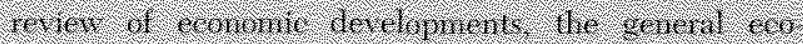

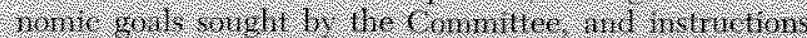

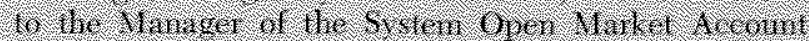

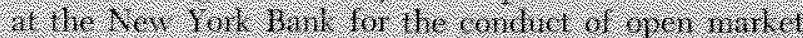

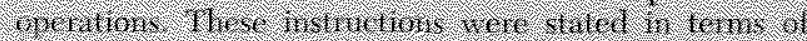

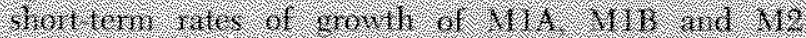

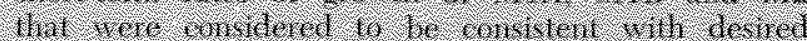

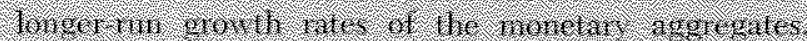

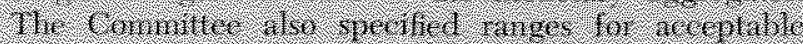

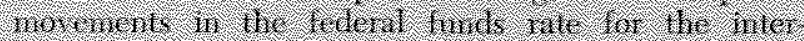

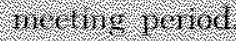

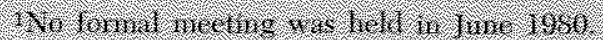

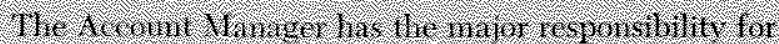

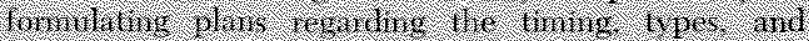

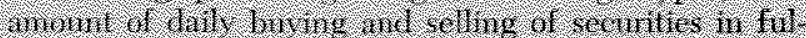

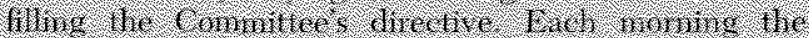

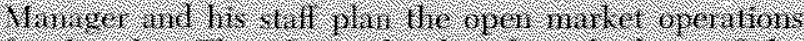

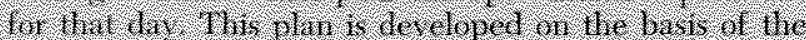

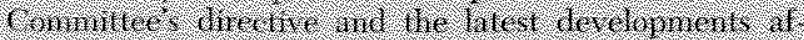

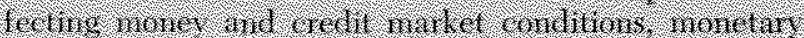

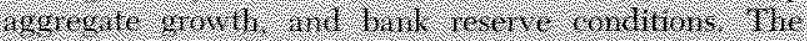

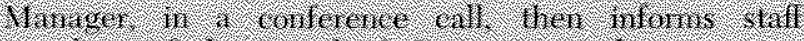

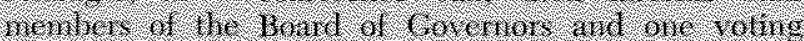

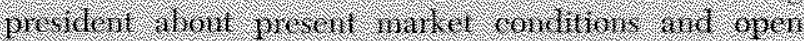

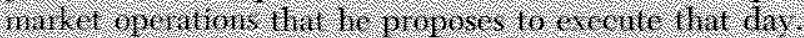

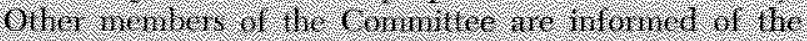

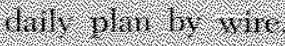

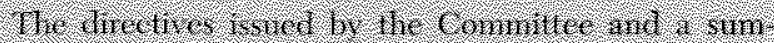

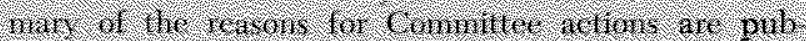

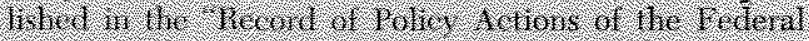

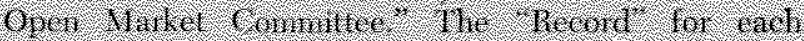

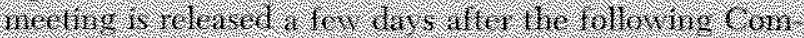

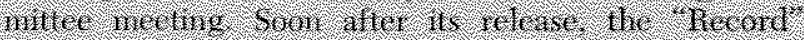

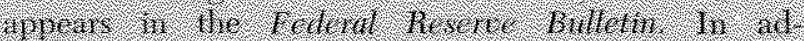

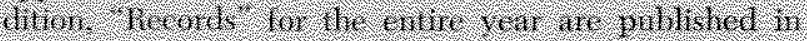

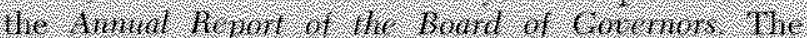

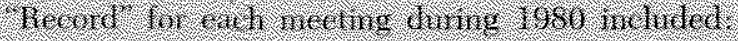

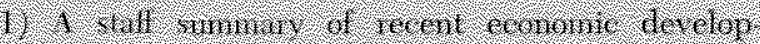

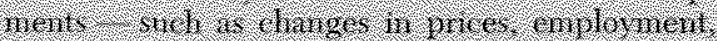

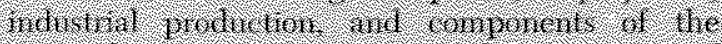

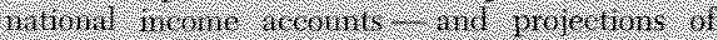

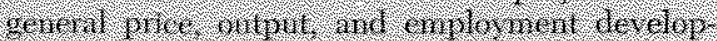

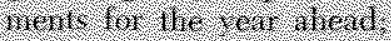

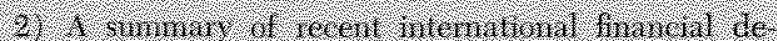

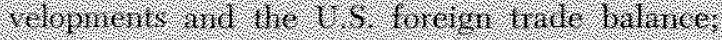

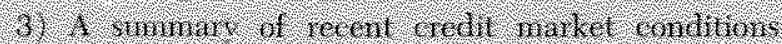

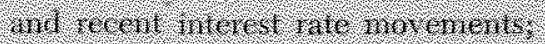

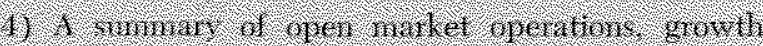

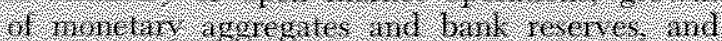

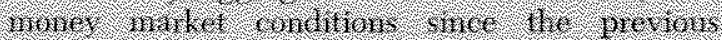
meetrict

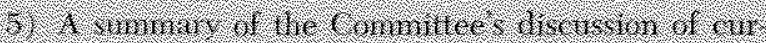

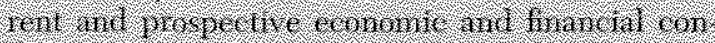

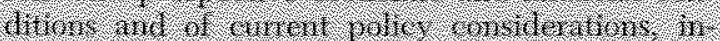

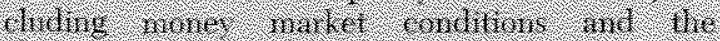

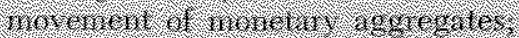

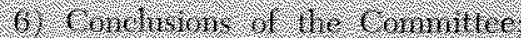

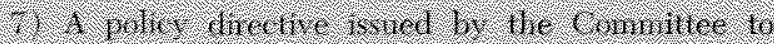

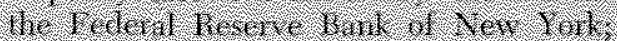

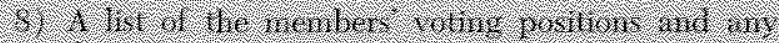
Ascrinine vowmarat:

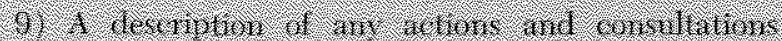

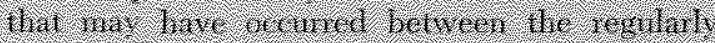

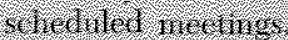


One objective of the revisions was to inchude in a narrow monetary aggregate the increasing number of transaction-type accounts available at commercial and mutual savings banks, savings and loan associations and credit mions. The M1A definition of the money stock is the same as old Ml except that it excludes demand deposits held by foreign commercial banks and official institutions. The MIB definition includes M1A plus other checkable deposits, which include automatic trunsfer service (ATS) accounts, negotiable order of withdrawal (NOW) accounts, credit union share drafts, and demand deposits at thrift institutions.

Financial innovations that caused difficulty in interpreting the growth of a narrow monetary aggregate in recent vears included the permission for all commercial banks to offer ATS accounts, and for all depository institutions in the state of New York to offer NoW accounts. Both changes occurred in the fall of 1978 . The difference between the growth rates of MIA and MLB indicates the problems the Committee faced in evaluating the growth of old M1 in 1979 relative to previous years. From IV/1978 to IV/1979, M1A increased 5 percent - the same as old Ml - compared with a 7.4 percent increase in the previous year. ${ }^{-4}$ In contrast, the growth of MIB slowed less in 1979 , increasing 7.7 percent from IV/1978 to IV/1979, compared with an 8.2 percent increase from IV $/ 1977$ to $I V / 1978$. Thus, a small reduction in the rate of monev growth, measured as $\mathrm{MIB}$, would ap pear to be a very sharp slowing in money growth if checkable deposits other than demand deposits at commercial banks are excluded from the measure of the money supply.

Another objective of these revisions was to capture in a broader aggregate the effects of other financial innovations. For example, shares in money market mutual funds and overnight repurchase agreements at commercial banks, which are close substitutes for assets in the narrower aggregates, are included in the new $\mathrm{M} 2$ measure.

\section{ANNUAL TARGETS FOR 1980}

The Full Employment and Balanced Growth Act of 1978 (also called the Humphrey-Hawkins Act) requires the Committee to announce before Congress in February of each year growth ranges for monetary and credit aggregates over the current calendar year.

4Crowth of old MI was also ahout the sane as growth of MIA in $1978-72$ pereent from IV/1977 to IV/1978. Growth rates of monetary aggregates referred to in this article reflect dinta revised as of January 1981.
The Committee has chosen to establish these ranges from the fourth quarter of the previous year to the fourth quarter of the current year." These ranges must be reviewed before Congress in July of each year, although the Committee may reconsider the annual ranges at any time." The period to which the anmual ranges apply, however, may not be changed. Thus the base period (the fourth quarter of the prior year) remains the same even if the Committee should change the desired growth rates of the aggregates for the year.

Table 1 indicates the annual growth targets the Committee adopted for the new aggregates at its meeting in February 1950. The targets established for 1980 represented reductions in the growth rates of the aggregates from 1979. The midpoint of the range for MlA in 1950 was 4.75 percent, compared with an actnal 5 percent increase in 1979. The deceleration would be especially marked for M1B; the midpoint of the M1B range for 1980 was 5.25 percent, compared with growth of 7.7 percent in 1979.

These ranges reflect the Committee's objective of slowing money growth in 1980:

In the Conmittee's discassion of the ranges for the coming year, the members agreed that monetary growth should slow further in 1980, following some deceleration over 1979 , in line with the continuing objective of curbing inflation and providing the basis for restoration of economic stability and sustainable growth in output of goods and services."

The "Record" of the Committee's February meeting, however, indicates that there were some differences of view regarding the appropriate aggregates to be specified as targets, because of uncertainty about the impact of shifts between savings accounts and interest-earning ATS and NOW accounts:

Frior to 1979 , the Committee adopted one-year growth rates each auarter, and the base period for the ammal targets announced each quarter was bronght forward to the most recent quarter. This method resulted in a problem referred to as "base drift." Growth in an aggregnte above (below) an annul growth range in a quarter woukd raise (lower) the base level for calculation of the next annual growth path. Specification of anmat objectives in terms of calendar year growth rates, which eliminates the base drift problem within a calendar year, does not solve this problem from one calendar year to the fext since new ranges are established from the end of each calendar year.

"At its midmear review of the annual ranges, the Committe also establishes tentative ranges for the nonetary aggregates for the next year - measured from the fourth quarter of the current year to the fourth quarter of the following year.

7"Record" (April 1980), p, 329; and "Monetary Policy Report to Congress," Federal Reserve Bulletin (March 1980), p. 178.

$8^{2 c}$ Record" (April 1980), p. 329 . 


\section{Table 1}

\section{Planned Growth of Monetary} Aggregates for 1980 (percent changes, fourth quarter to fourth quarter)

\begin{tabular}{|c|c|c|}
\hline Agorerarre & $\begin{array}{l}\text { eroposed } \\
\text { praige }\end{array}$ & growntal \\
\hline hnll & $3560 \%$ & $50 \%$ \\
\hline MIE & 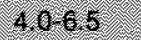 & 77 \\
\hline 12 & 6.0 .9 .6 & 9.0 \\
\hline No & 6.50 .5 & 8.8 \\
\hline
\end{tabular}

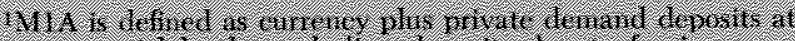

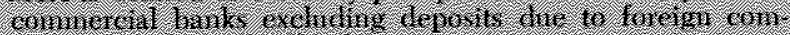

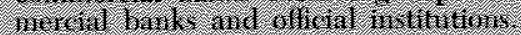

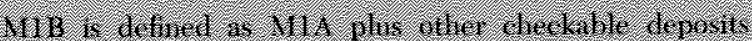

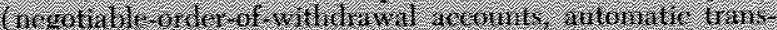

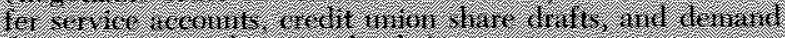

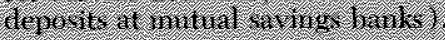

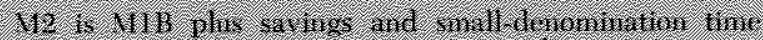

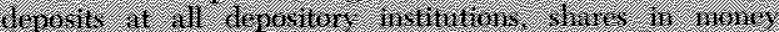

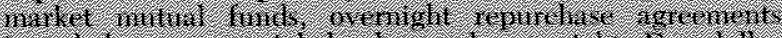

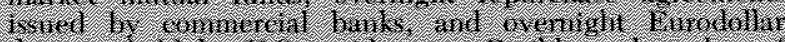

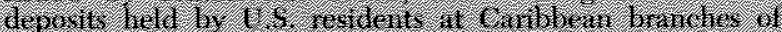
U.

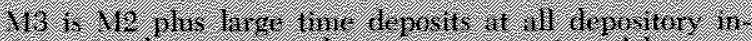

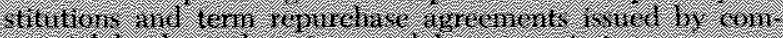
n.t.

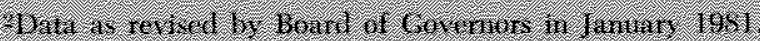

Wilh respect to $M 1 A$, its growth would be dampened in the event of enactment of nationwide NOW account legislation and, as would be expected, a large transfer of funds from demand deposits to NOW accomts. In support of retaining MIA on the list, however, it was noted that enactment of the legislation would tend to distort growth of M1B also - in the opposite direction as a result of transfers of funds from savings deposits to NOW accounts mand no doubt would lead the Committee to reconsider what ever ranges it adopted at this meeting. ${ }^{3}$

As depositors shifted funds from non-interest-earning checking deposits to ATS and NOW accounts, M1A would be expected to decline and M1B to increase. An analysis by the Board staff of recent experience with ATS and NOW accounts, especially in the Northeast, indicated that the flow of funds from demand and savings deposits would account for most of the growth of interest-earning checkable accounts. Surveys indicated that roughly two-thirds of the funds flowing into ATS and NOW accounts would come from demand deposits and roughly one-third from savings deposits. In early 1980, however, the Com-

Nibid. mittee assumed that the public's adjustment process was about complete and that the growth rates of the two aggregates would differ only by about one-half percentage point for the year. ${ }^{10}$ For this reason, the annual ranges for MIA and MIB announced in February differed by only one-half percentage point.

\section{ACTUAL MONEI GROWTH AND THE ANNUAL RANGES}

From the fourth quarter of 1979 to the fourth quarter of 1980, MIA and M1B increased 5 percent and 7.3 percent, respectively. Thus, the growth of M1A was within its preannounced anmual range, but the growth rate of MiB exceeded the top of its range by 0.8 percentage points.

Though the Committee's target ranges for the growth of the monetary aggregates in 1980, which were first established at the February meeting, allowed for a difference of only 50 basis points in growth rates of MIA and MIB, the difference turned out to be about 230 basis points. In interpreting the influence of the growth in ATS/NOW accounts on the growth of monetary aggregates in 1980, the Federal Reserve Board estimated that M1A growth was about 125 basis points higher and MIB growth was about 50 basis points lower than the actual recorded data. ${ }^{11}$ Effects of the unanticipated growth of ATS/NOW accounts on the growth of MIA and M1B relative to annual ranges are illustrated in chart 1 . In those charts the levels of those aggregates are not adjusted for the growth of ATS/NOW accounts, but the dashed lines are the annual ranges adjusted for the growth of ATS/ NOW accounts: the annual growth rates for MIA are reduced by 125 basis points, while those for M1B are increased by 50 basis points. With the annual ranges adjusted in this manner, the growth rates of M1A and M1B each exceeded the top of their adjusted annual ranges by about 25 basis points.

The significance of money growth during 1980 for the rate of inflation depends on how rapid money growth was relative to the trend growth rate of recent years, since the rate of inflation tends to be related to the trend of money growth over several vears. ${ }^{12}$ In the three years ending IV/1979, M1B increased at an 8

10"Monetary Report to Congress," Federal Reserve Bulletin (March 1980), p. 178 .

11 Monetary Policy Objectives for 1981 (Board of Governors of the Federal Reserve System, 1981), p. 5 .

12 Albert E. Burger, "What Happened to the Economy in the First Half of 1980?" this Reviete (August/September, 1980) pp. 9-15; Keith M. Carlson, "The fag from Money to Prices," this Review (October 1980), pp. 3-10. 
chart

Ranges for MIA and MIB for Period IV /1979 to IV /1980

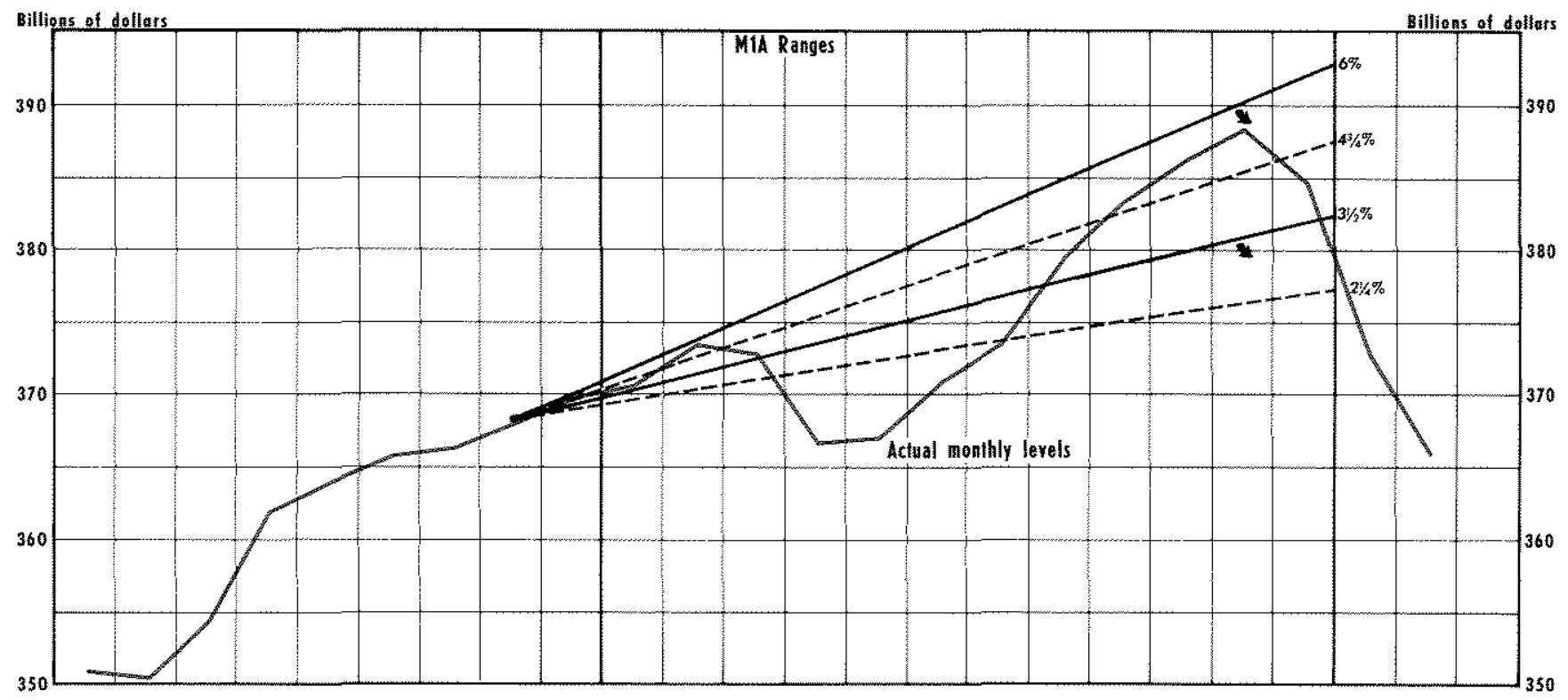

Billoas of dellars

Biltions of dollars

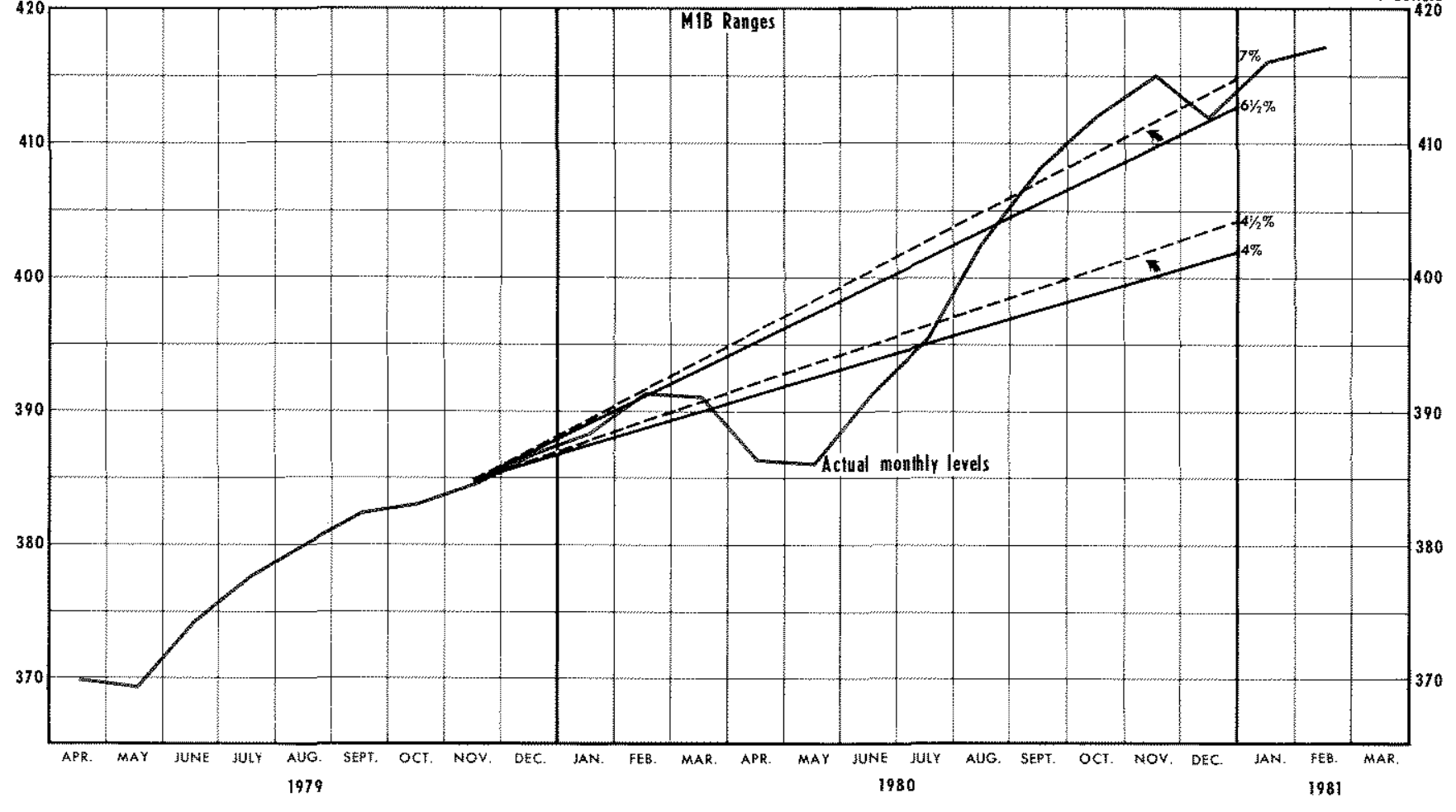

percent amnual rate. The 7.3 percent increase in $\mathrm{M} 1 \mathrm{~B}$ in 1980 represents a small reduction in the rate of money growth relative to the trend in the previous three years, but not as great a reduction as indicated by the Committee at the beginning of the year. In the February 1981 Monetary Policy Report to Congress,
M1B is adjusted for the effects of shifts of savings deposits into ATS/NOW accounts by reducing the growth rate for 1980 by 50 basis points. Even with that adjustment, the growth of M1B in 1980 exceeded the midpoint of the annual range by about 150 basis points. 


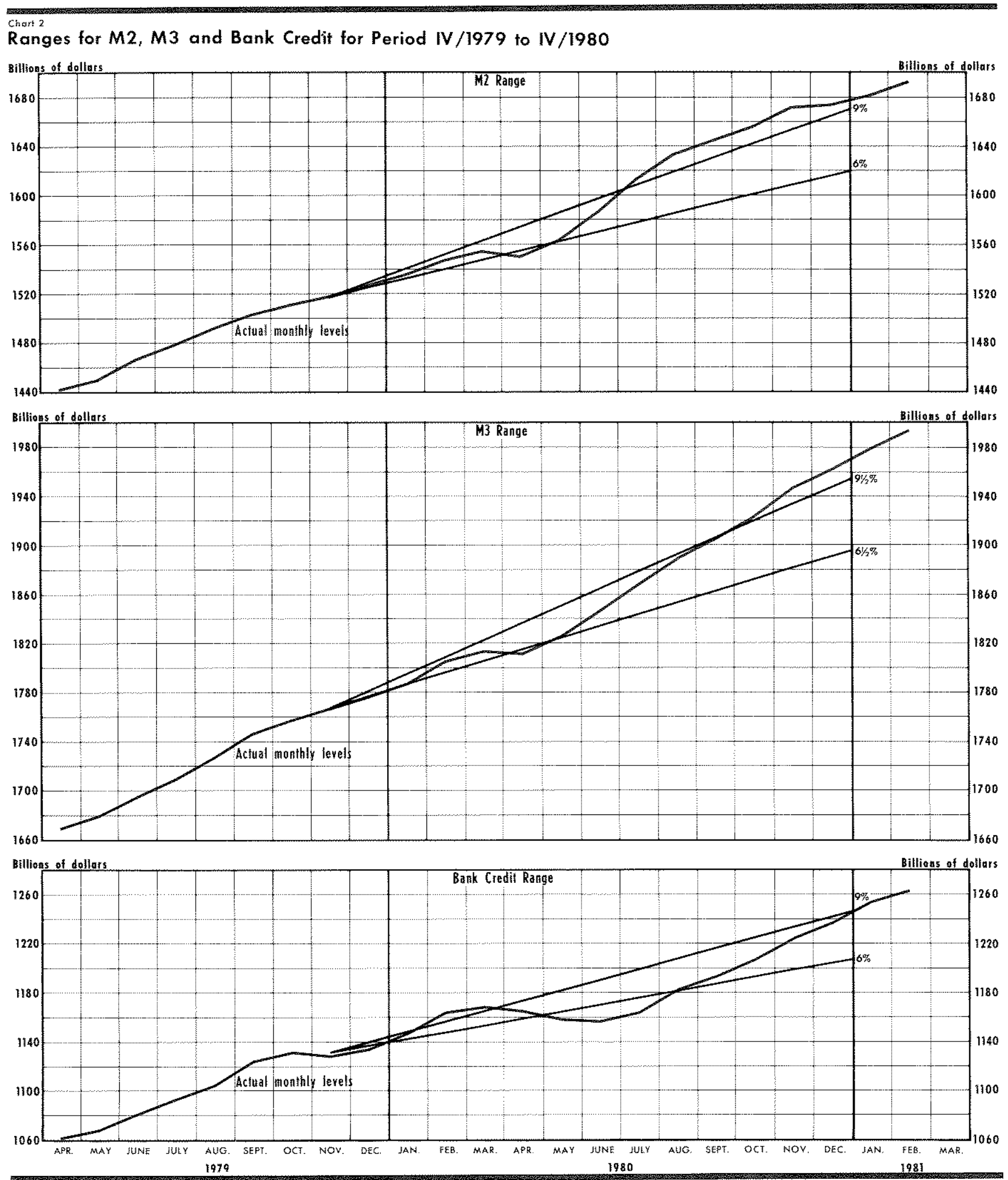

The expansion of the broader monetary aggregates, M2 and M3 (chart 2), also exceeded targets for the year, increasing 9.8 percent and 10 percent, respec- tively (IV/1979 to IV/1980). The growth of bank credit was 8 percent for the year, consistent with the adopted range of 6 to 9 percent. 


\section{THE NATURE OF THE SHOPT TERM DIPECTIVE}

The annual target ranges announced $b y$ the Committee set broad guidelines for Federal Reserve actions during the year. Decisions of the Committee that influence the day-to-day implementation of monetary policy are specified in the short-term policy directives, which are issued by the Committee at each meeting to the Manager of the Open Market Account at the Fedeml Reserve Bank of New York. At each meeting in 1950, the Committee specified short-term growth rates for M1A, MIB and M2. ${ }^{13}$ These short-term objectives for money growth are chosen by the Committee to guide open market operations over intermeeting periods. The Committee also specifies ranges for acceptable movements in the federal funds rate for intermeeting periods.

The short-run directives adopted at Committee meetings since October 6,1979 , contrast sharply with directives issued prior to that time. ${ }^{14}$ The differences reflect increased emphasis on monetary control and reduced emphasis on confining movements of the federal funds rate. For example, the directive adopted at the April 22, 1980, meeting stated:

In the shote run, the Committee seeks expansion of reserve argregates consistent wih growth over the first half of 1980 at an anmual ate of 4.5 percent for MIA and 5 percent for M1B, or somewhat less, provided that in the period before the next regular meeting the weekly average federal funds rate re. mins within a range of 13 to 19 pereent. The Comm mittee believes that, to be consistent with this shorturu policy, $\mathrm{M} 2$ should grow at an anmal rate of about 6.75 pereent over the first half and that lank credit should grow in the months ahead at a pace compatible with growth over the year as a whole within the range agreed upon.

If it appears during the period before the next meeting that the constraint on the federal funds rate is inconsistent with the objective for the expansion of reserves, the Manager for Domestic Operations is promptly to notify the Chaiman who will then decide whether the situation calls for supplementary instructions from the Committee."15

\footnotetext{
13. At neetings pror to fuly 1980, growth rates adopted for $\mathrm{M} 2$ werte cited as those deemed to be comsistent with objectives adopted for $\mathrm{M}$ lA and $\mathrm{M} \perp \mathrm{B}$. Beginning with the luly meeting, the Commitee has stated slort-ten oljectives for growth of M2 along with objectives for growth of $\mathrm{MlA}$ and MLB.

4For an historical perspective on the Committee's short-nun operating procedures, see Henry C. Wallich and Peter M. Keir, "The Role of Operating Guides in U.S. Monetary Policy: A Historical Review," Fedeval Reserve Bulletin (September 1979), pp. 679-91.

15“Record" (June 1980), p. 488.
}

At each meeting prior to adopting the new approach to implementing monetary policy, the Committee specified its short-run objective for the growth of each monetary aggregate as a range of growth rates over a two-month period (the month of the meeting and the month after the meeting). The range for the growth rates of each monetary aggregate was usually several percentage points wide. The Committee set an intermeeting range for the federal funds rate, which was generally no more than one percentage point wide, and specified an initial level of the federal funds rate that was thought to be consistent with the short-run ranges set for $\mathrm{M} 1$ and $\mathrm{M} 2$. Growth rates of $\mathrm{M} 1$ and $\mathrm{M} 2$ relative to the two-month ranges were intended to serve as indicators of when the federal funds rate should be allowed to change within its range. For example, the directive of the Committee from the meeting on September 18, 1979, read:

Faxly in the period before the next regular meeting, System open market operations are to be directed at attaining a weekly average federal funds rate slightly above the current level. Subsequenty, operations shall be directed at maintainitrg the weekly average federal funds ate within the range of 11.25 to 11.75 percent. In deciding on the specific objective for the fecleral funds rate, the Manager for Domestic Operations shall be guided mainly by the relationship between the latest estimates of annual rates of growth in the September-October period of M1 and $\mathrm{M} 2$ and the following ranges of tolerance: 3 to 8 percent for $\mathrm{M} 1$ and 6.5 to 10.5 percent for $\mathrm{M} 2$. If rates of growth of MI and Mo, given approximately equal weight, appear to be close to or beyond the upper or lower limits of the indicated ranges, the objective for the funds rate is to be raised or lowered in an orderly fashion within its range. ${ }^{16}$

The significance of these changes in the directive is that, under the old procedure, open market operations were directed toward maintaining the federal funds rate within a narrow range as long as growth rates of monetary aggregates stayed within specified ranges, whereas, under the new procedure, open market operations are directed toward hitting targeted growth rates for monetary aggregates, as long as the federal funds rate remains in a relatively wide range.

As a result of the changes instituted since October 6,1979 , the Manager of the System Open Market Account, who is responsible for implementing the Committee's directives, has had to change the focus of domestic open market operations from maintaining a weekly average federal funds rate within a specified range to maintaining the growth of "reserve aggre-

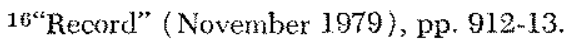


chart 3

FOMC Ranges for the Federal Funds Rate

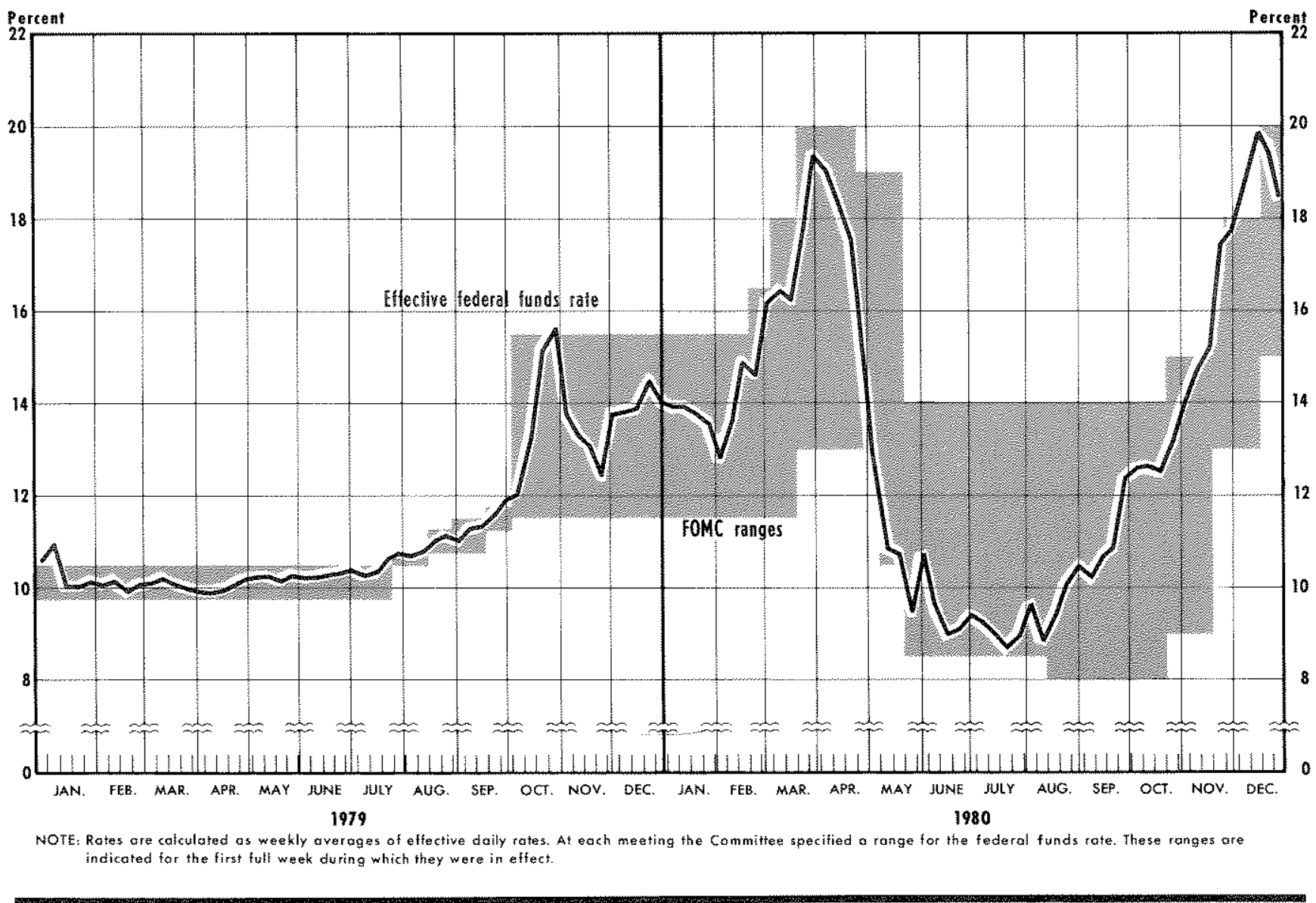

gates" consistent with specified growth rates of M1A, $\mathrm{M} 1 \mathrm{~B}$ and M2. Growth rates of reserve aggregates are not specified in either the directive or the Record of Policy Actions. The Committee votes on growth rates of the monetary aggregates, not the reserve aggregates. Consequently, it is left to the staffs of the Board of Governors and the Open Market Desk of the Federal Reserve Bank of New York to establish guidelines for the growth of these reserve aggregates consistent with the Committee's objectives.

The Committee has assigned a less eritical role to the federal funds rate in guiding open market operations under the new operating procedure. The Federal Reserve made the following statement about the role of the constraint on the federal funds rate in its report to Congress on monetary policy in 1980 :

The [Committe] has continued to set broad ranges of tolerance for money market interest rates - generally specified in terms of the federal funds rate. These ranges, however, shonld not be viewed as rigid constraints on the Open Market Desk in its pursuit of reserve paths set to achieve targeted rates of monetary growth. They have not, in practice, served as true constraints in the period since October 1979, as the Committee typically liss altered the ranges when they have become binding. But, in a wonld of uncertainty about economic and finantial relationships, the ranges for interest rates have served as a useful triggering mechanism for discussion of the implications of current developments for policy. ${ }^{1 \tau}$

\section{SHORT-TERM OBJECTIVES OF THE COMMITTEE IN 1980}

The growth rates of the monetary aggregates and the ranges for the federnd funds rate specified by the Committee at meetings in 1930 are presented in table 2. Chart 3 displays the weekly average federal funds rate and ranges for the federal funds rate voted by the Committee during 1979 and 1980. During 1980 , the width of the range for the federal funds rate was between 4 and 8.50 percentage points. On several

17"Monetary Policy Report to Congress," Federal Reserue Bulle$\operatorname{tin}$ (Mareh 1981), p. 204 . 
Table 2

FOMC Operating Ranges -1980

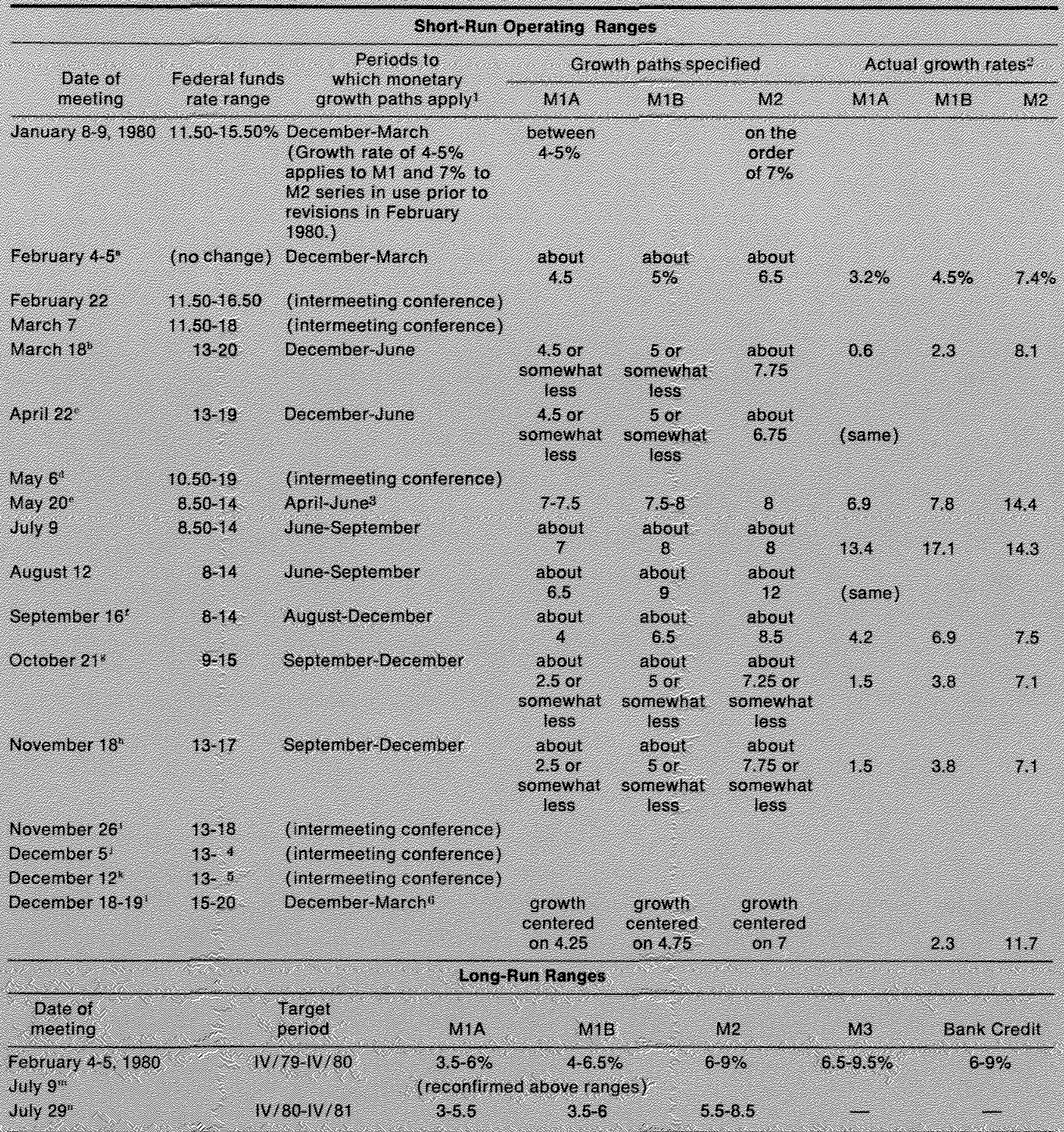

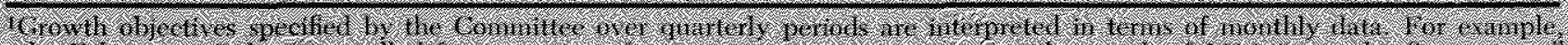

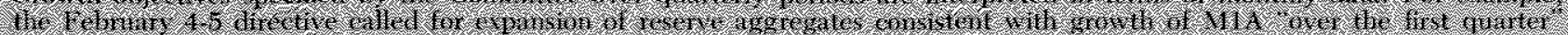

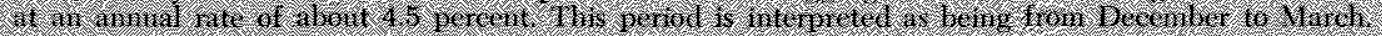

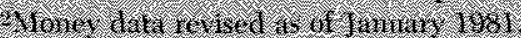

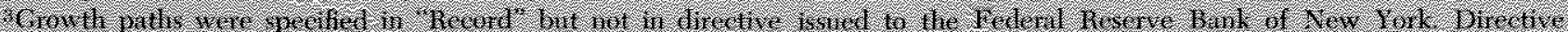

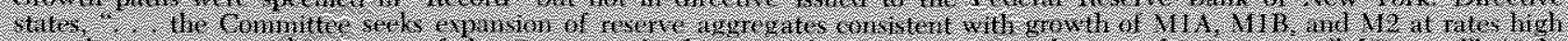

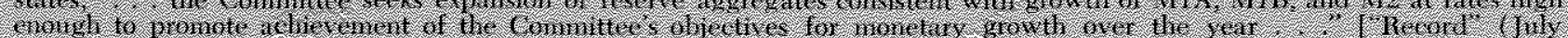
1980.0 .6 .6611

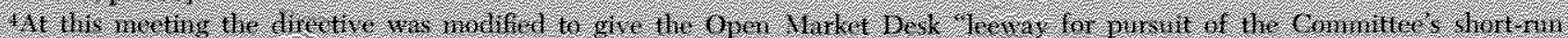

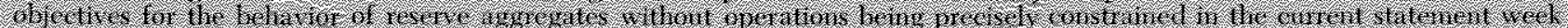

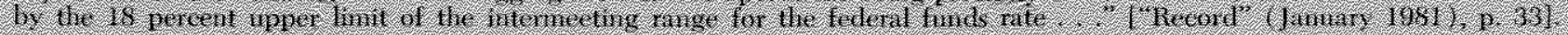

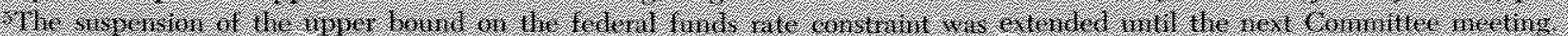

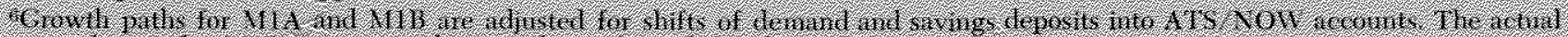

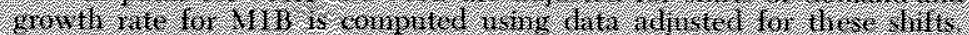


Table 2 (continued)

\section{Footnotes - Dissents to FOMC Actions}

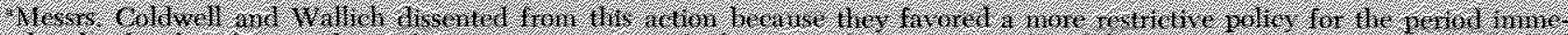

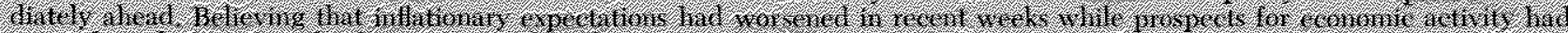

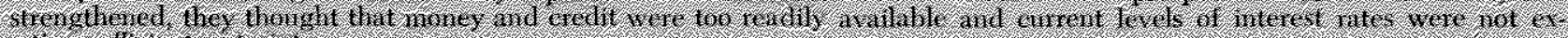

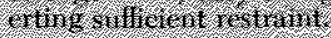

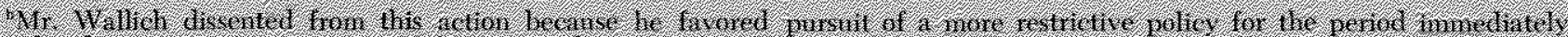

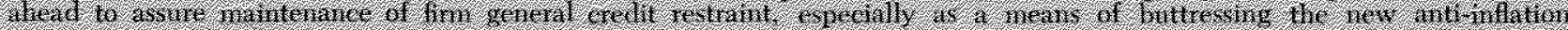
Timstiti:

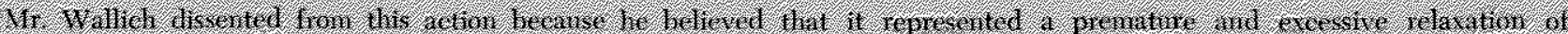

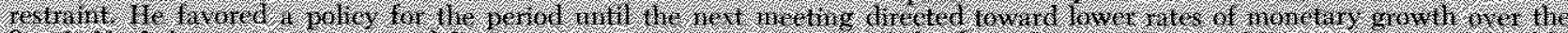

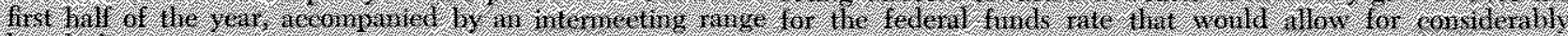

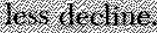

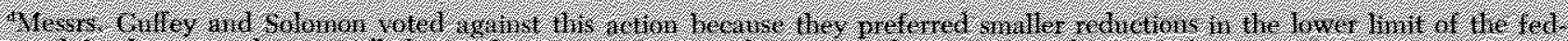

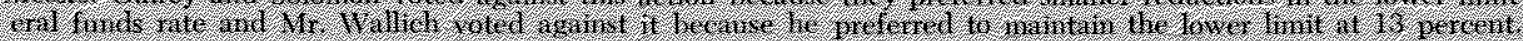

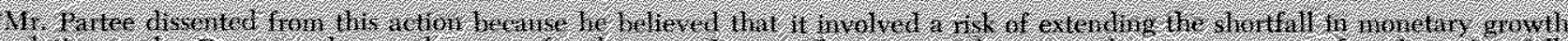

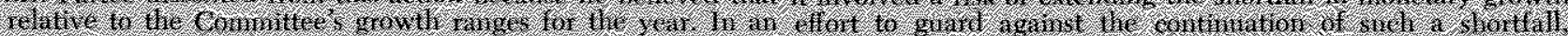

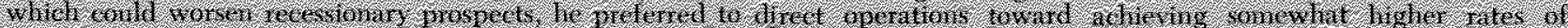

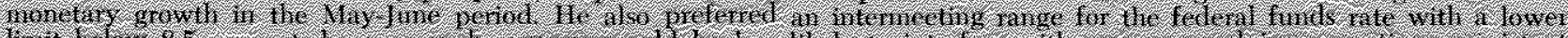

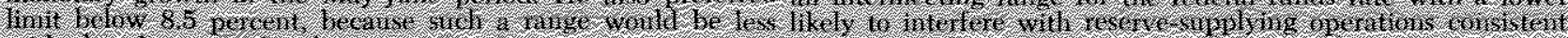

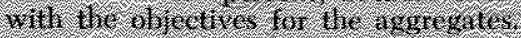

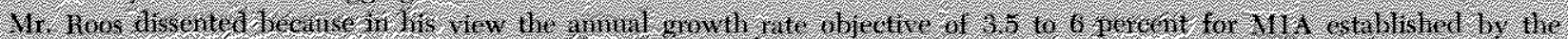

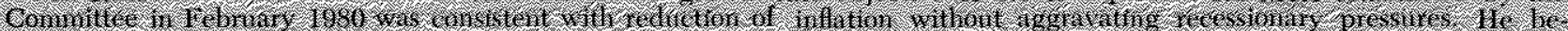

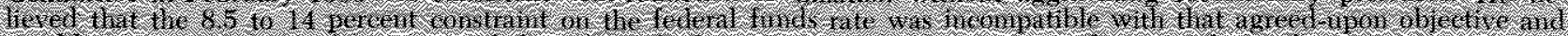

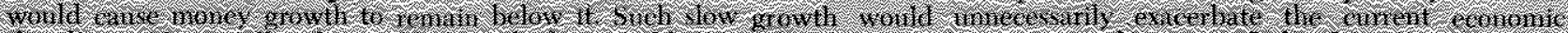

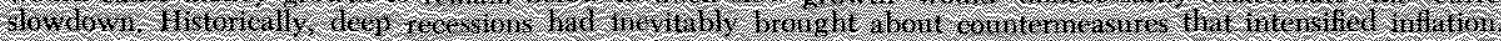

Th

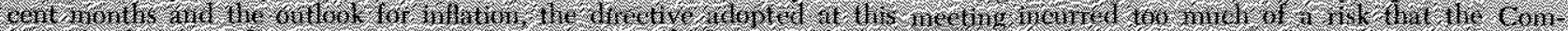

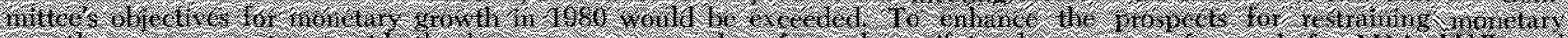
s.

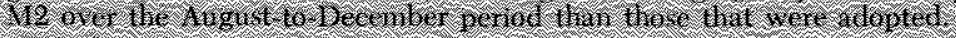

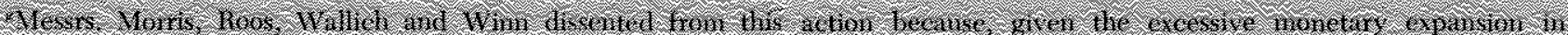

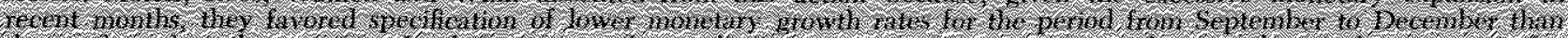

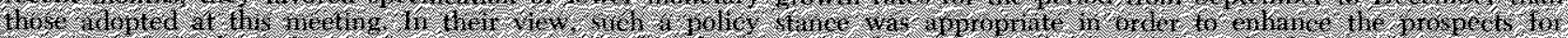

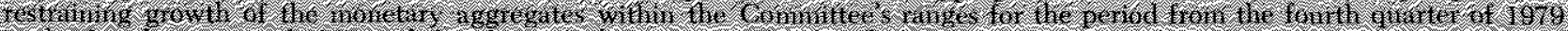

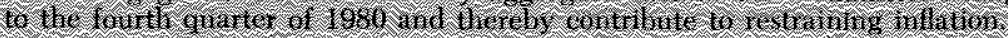

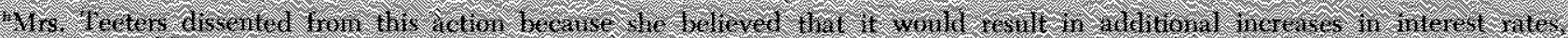

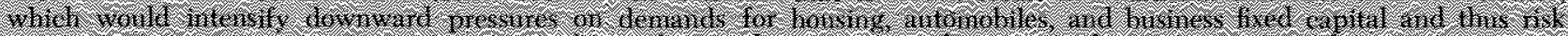
H.

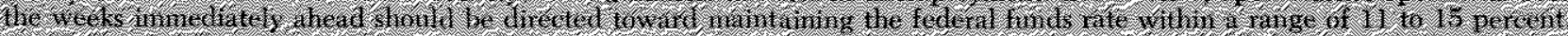

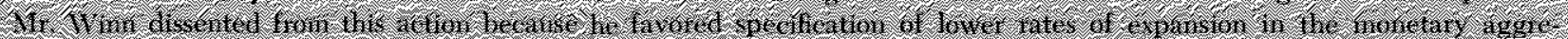

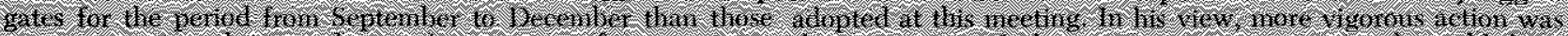

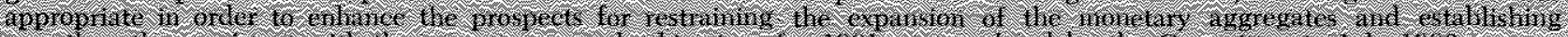

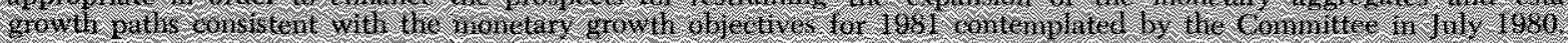

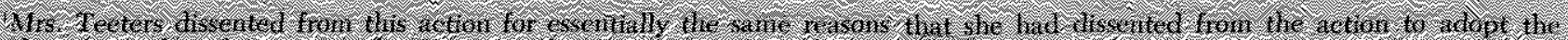

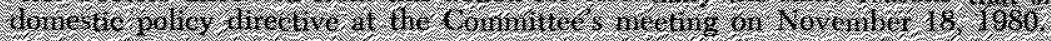

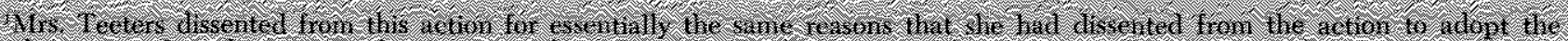

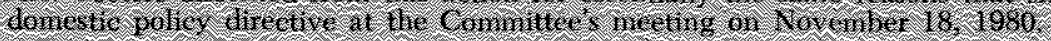

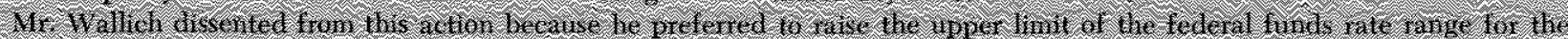

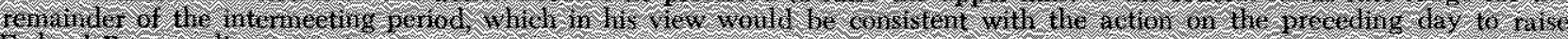

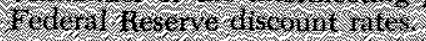

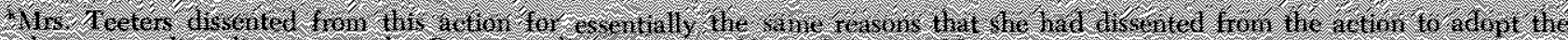

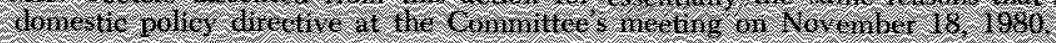

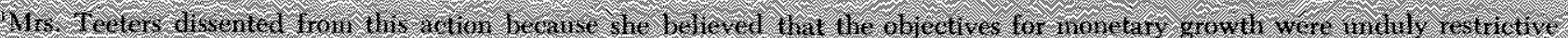

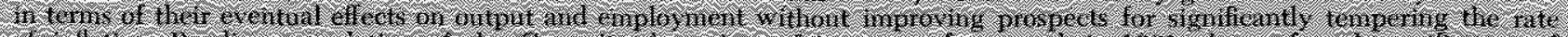

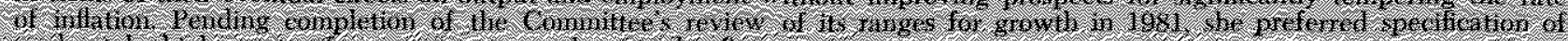

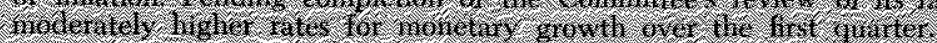

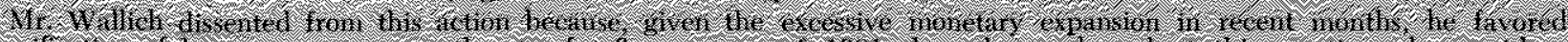

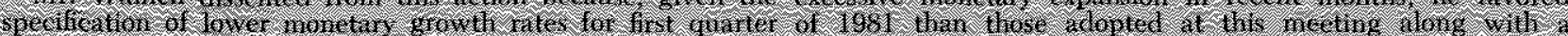

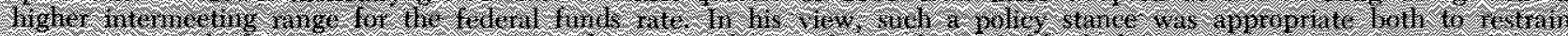

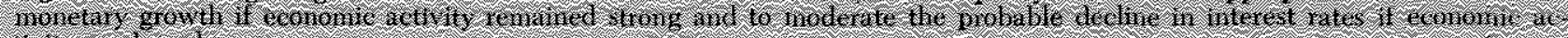
tiviturenteried.

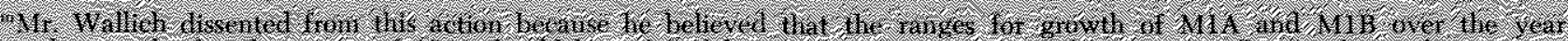

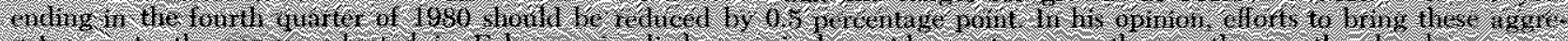

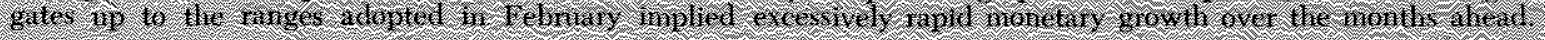

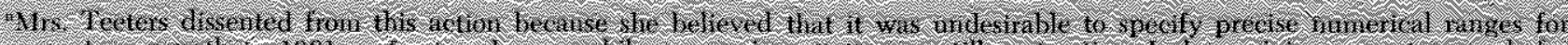

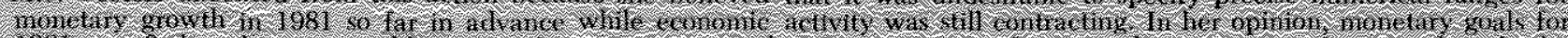

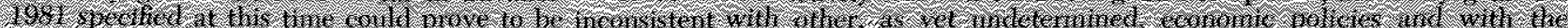

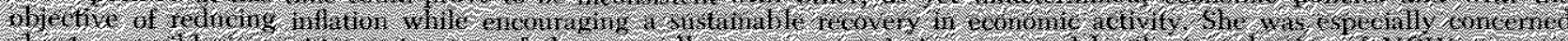

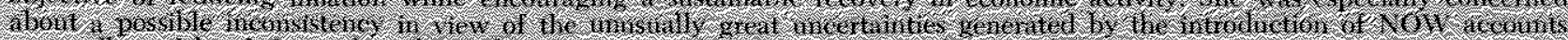

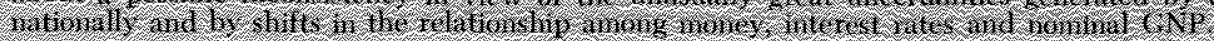


Chart 4

\section{Growth Objectives for MIB}

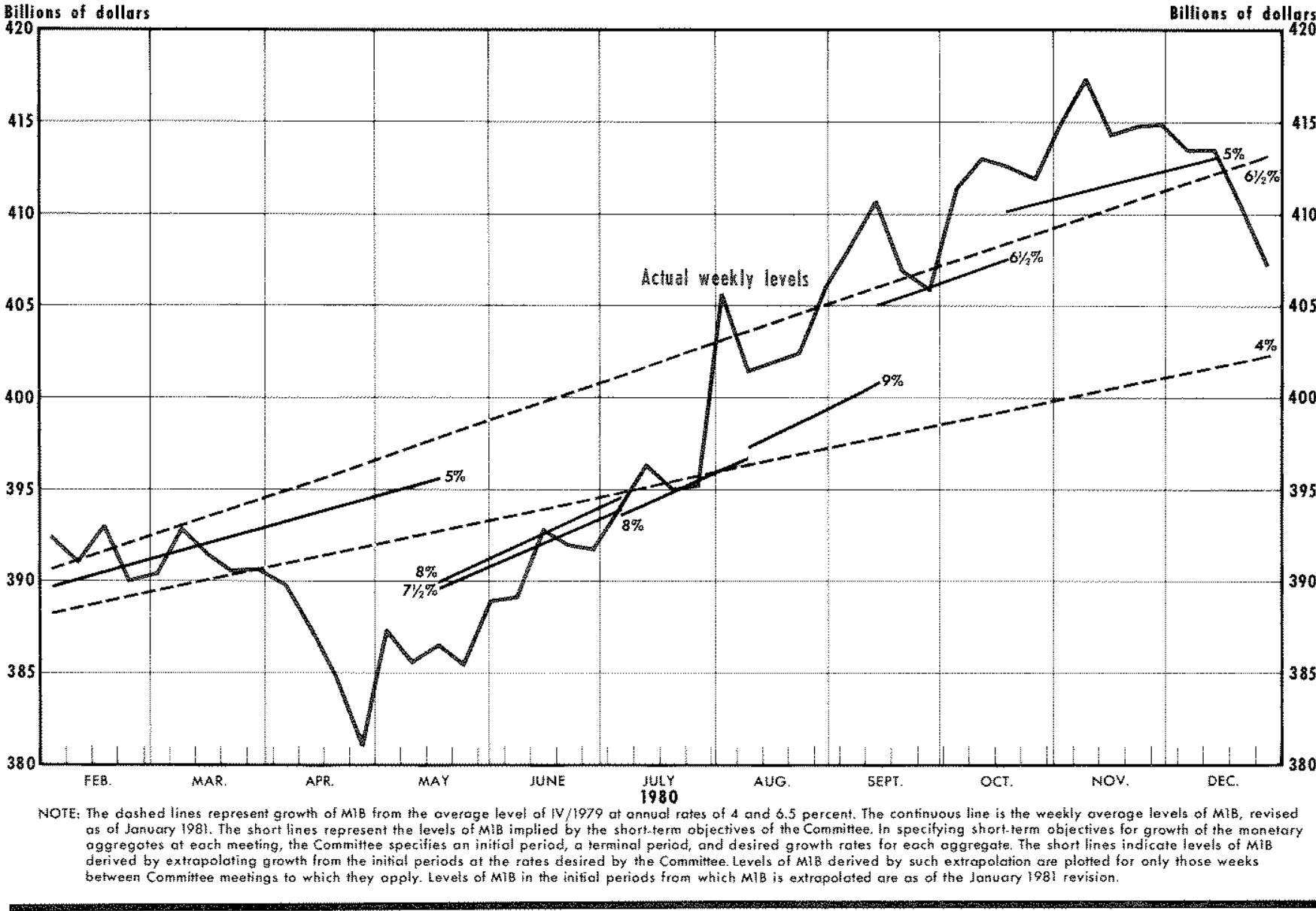

occasions, however, the federal funds rate moved near or outside the ranges spectied by the Committee. Consequently, the ranges specified by the Committee in 1980 do not appear to have constrained Federal Reserve actions in the same manner as under the prior operating procedure.

During much of the year, MlB was outside the annual target range, plotted in chart 4 as the cone representing growth from $I V / 1979$ at annual rates between 4 and 6.5 percent. From April through July, MIB was below the annual target range and, from September through part of December, above the annual target range. This fluctuation of MIB about the annual target range indicates either that the Committee specified short-term oljectives for the growth of M1B that were outside the annual target range, of that MLB deviated substantially from the Committee's short-term objectives during much of the year.

Chart 4 presents the relation of the short-term objectives of the Committee to the annual target range, and deviations of M1B from the short-term objectives. Until late in the fall of 1980 , the short-term objectives for MLB were either within the anntal target range or on growth paths consistent with retuning to the annual range. At the meeting in February, the Committee voted for growth of MIB at about a 5 percent rate from $I V / 1979$, and at meetings in March and April, for growth from IV/1979 at a rate of 5 percent or somewhat less. At meetings in May, July and Aulgust, the Committee voted for growth mites faster than the annual objectives, to gradually bring $\mathrm{MIB}$ from levels below the annual range to within the annual range. The shortterm objective for M1B voted at the September meeting implied growth near the top of the annual range. Until the meeting in October, therefore, movement of M1B outside the annual target range reflected deviations of money growth from the short-term objectives.

After the meeting in September, MIB increased rapidly, rising several billions of dollars above the 
annual target range. At meetings in October and November, the Conmittee specified growth rates of the aggregates from the average level of September; consequently, the short-term objectives for MIB voted at those meetings implied levels above the annual target range. The discussion at the Committee meetings in October and November, summarized in the appendix indicates that Committee menbers were concened about the effects of increases in interest rates that might have resulted from a policy of binging money growth down to within the annual range.

\section{THE USE OF THE NEW PROCEDURE TO CONTROL MONEY GROWTH}

The wide fluctuations of $\mathrm{M} \perp \mathrm{B}$ about the anntal target range over most of 1980 reflected deviations of MIB from the short-term objectives of the Committee. In analyzing monetary policy actions in 1980, therefore, it is important whether the deviations of M1B from the short-term objectives reflect problems with the control of money growth that are basic to the procedure, or reflect constraints placed on the use of the procedure that are not explicitly stated in the directives of the Committee.

The procedure for implementing monetary policy adopted on October 6, 1979, involves using open market operations to meet specific objectives for the levels of nonborrowed reserves (NBR). Prior to October 6 , 1979 , in contrast, the objective of open market operations was to keep the federal funds rate within the range specified by the Committee at the last meeting. Because the objective of open market operations under the current operating procedure is to control NBR, the federal funds rate changes in the direction of changes in the demand for reserves. The major policy actions under the current operating procedure are changes in the objective for NBR and changes in the discount rate.

\section{Determining Objectives for Nonborrowed Reserves}

Decisions of the Committee implicitly determine the objectives for NBR. After each Committee meeting, the staff of the Board of Governors estimates the average level of total reserves (TR) that is consistent with the short-rum objectives of the Conmittee for the growth of monetary aggregates. These avertge levels of TR (called TR paths) are specified for periods of three to five weeks between Committee meetings. When periods between Committee meetings are longer than five weeks, they are divided into two subperiods. and a TR path is calculated for each subperiod. ${ }^{\text {s }}$

The Committee decides on an initial level of borrowed reserves that is used in detemining the NBR path. Although this "borrowings assumption" is not a part of the official record of each Committee meeting, the staffs of the Board of Governors and the Federal Reserve Bank of New York consider it a decision of the Committee when planning open market operations

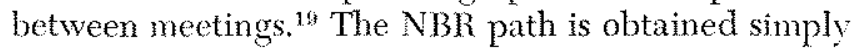
by subtracting the borrowings assumption from the TR path estimated by the staff of the Board of Governors. The objective of the Open Market Desk is to use open market operations to make the average level of NBR over the weeks between meetings of the Committee equal to the NBR path. To help the Open Market Desk gauge the effects of each day's open market operations on NBR, the NBR path is converted into weekly objectives for NBR.

18The measure of total reserves used in the reserve targeting procedure was dinged after the reserve requirement provisions of the Monetary Control Act of 1980 were implemented in November 1980 . Prior to that date, total reserves were measured as total reserves of nember banks, which includes their vanlt ass, plus reserve batances at Federal Reserve Banks. Federal reserve requirements were extended to all depository institutions in November 1980. Under the gradual phase--in of reserve requirements, most nonmember depository institutions hold vault cash that currently exceeds their required reserves. The mensure of total reserves used since November 1980 exchites this simplas vanlt cash (vantt cash less required reserves of institutions with vanlt cash in excess of their required reserves). Total reserves are now mensured as total reserve balances at Reserve Banks, plus total vault cash at all depository institutions subject to reserve requirenents, less the excess of vanlt cash over required reserves at institutions with valult cash in excess of their required reserves.

The statf of the Board of Covernors uses the following procedure to estimate the TR path for an intermeeting period. The staff calculates the average levels of the monetary aggregates on a seasonally adjusted basis over the weeks until the next intermeeting period that are implied by the vote of the Committee for growth rates of the aggregates. Average levels of the aggregates on a seasonally adjusted basis are converted to average levels on a nonseasonally adjusted basis. Growth of currency on a nonseasonally adjusted basis is estimated for the interneeting period and subtracted from the nonseasonally adjusted levels of the monetary aggregates associated with the vote of the Committee. The rest of the estimation procedire involves estimating the average level of TR that wold tend to yield the average levels of the monetary aggregates voted by the Committee, less estimated currency. That estimate of TR inclndes:

(1) an estimate of required reserves on liabilities of depository institutions not included in the monetary aggregates (stich as large certificates of deposit),

(2) required reserves on the level of transaction deposits implicitly voted by the Committes,

(3) an assumption about the average level of excess reserves.

${ }^{15}$ Fred J. Levin and Paul Meek, "Implementing the New Operating Procedures: "The View from the Trading Desk," Nete Monetary Control Procedures, vol. I, Federal Reserve Staff Study (Board of Governors of the Federal Reserve Systen, February 198:), p. 7 . 
The initial specifications of the path levels for TR and NBR are generally made on Friday after a Committee meeting. The Federal Reserve staff also makes a projection of what TR will be over the intermeeting period. Projections and path levels for TR are respecified approximately once each week. Projections of TR are respecified on the basis of additional information about the demand for reserves, and changes in the TR path are based on additional information about the relation between the monetary aggregates and TR. These so-called multiplier adjustments change the NBR path by the same amount as the TR path, and the weekly objectives for NBR are respecified such that the average of NBR over the period will equal the new path level.

If the revised projection of TR is substantially dif ferent from the new specification of TR, the NBR path might be changed to keep T'R closer to path, reducing (increasing) the NBR path if $\mathrm{TR}$ are projected to be above (below) the TR path. On several occasions the NBR path was changed in this manner between Committee meetings by the senior Board staff and the management of the Open Market Desk, in consultation with the Chairman of the Federal Reserve Board.

\section{Controlling Money Growth by Targeting on Nonborrowed Reserves}

Projections of average levels of $\mathrm{TR}$ over intermeeting periods provide a guide to policy actions. A deviation of a projection of TR from the path level indicates that changes in the supply of NBR or the discount rate are appropriate to avoid a deviation of money growth from the short-term objectives of the Committee. If TR are projected to exceed the TR path, appropriate actions would be to reduce the path level for NBR, raise the discount rate, or both. Reducing the NBR path with the TR path unchanged involves increasing the implied level of borrowings. Rem ductions in the NBR path and increases in the discount rate tend to increase the federal funds rate and reduce the amount of reserves demanded by the banking system. If, in contrast, TR are projected to be below path, the actions that would be appropriate to speed the return of the money stock to the targeted level are to increase the NBR path, reduce the discount rate, or both.

There are various reasons why money growth might have deviated from the short-term objectives of the Committee under this operating procedure. One reason could have been that the path levels for TR were inconsistent with the short-term objectives for money growth, even after adjustments during intermeeting periods. With errors in specifying TR paths, the Federal Reserve could have taken actions to keep TR near path levels and yet miss the objectives for money growth.

Another possibility is that, even if the TR paths were specified accurately, errors in projecting TR could have caused the Federal Reserve to take actions that turned out to be inappropriate for keeping TR near the path level. A final possibility is that projections of TR relative to path levels indicated the actions that would have been appropriate to meet the short-term objectives for money growth, but for some reason, those actions were not taken.

\section{EXPERIENCE WITH MONETARY CONTROL UNDER THE RESERVE TARGETING PROCEDURE}

In most intermeeting periods, the path levels and projections of TR were reasonably accurate. Thts, the differences between the projections and path levels of TR generally indicated the nature of policy actions that would have been appropriate to keep money growth from deviating substantially from short-term objectives.

A notable exception to this general conclusion applies to the intermeeting period that began shortly after the imposition of credit controls. The Federal Reserve did not accurately project the effects of credit controls on the demand for reserves during that period; consequently, the differences between projections and path levels of TR did not indicate the actions that would have been necessary to prevent the decline of the money supply below target during that period. With the exception of this period, beginning shortly after the imposition of credit controls, money growth deviated most from the short-term ob. jectives of the Committee in those periods in which the Federal Reserve did not take the actions that the procedure indicated as appropriate for hitting money targets.

The large deviations of money growth from shortterm objectives occurred when interest rates were changing rapidly. In contrast, money growth was closest to short-term objectives in the summer, when short-term interest rates were below the discount rate and were relatively stable. A reluctance to take actions indicated by the procedure as appropriate for hitting money targets when short-term interest rates were 


\section{Table 3}

\section{The Credit Restraint Program of $\mathbf{1 9 8 0}$}

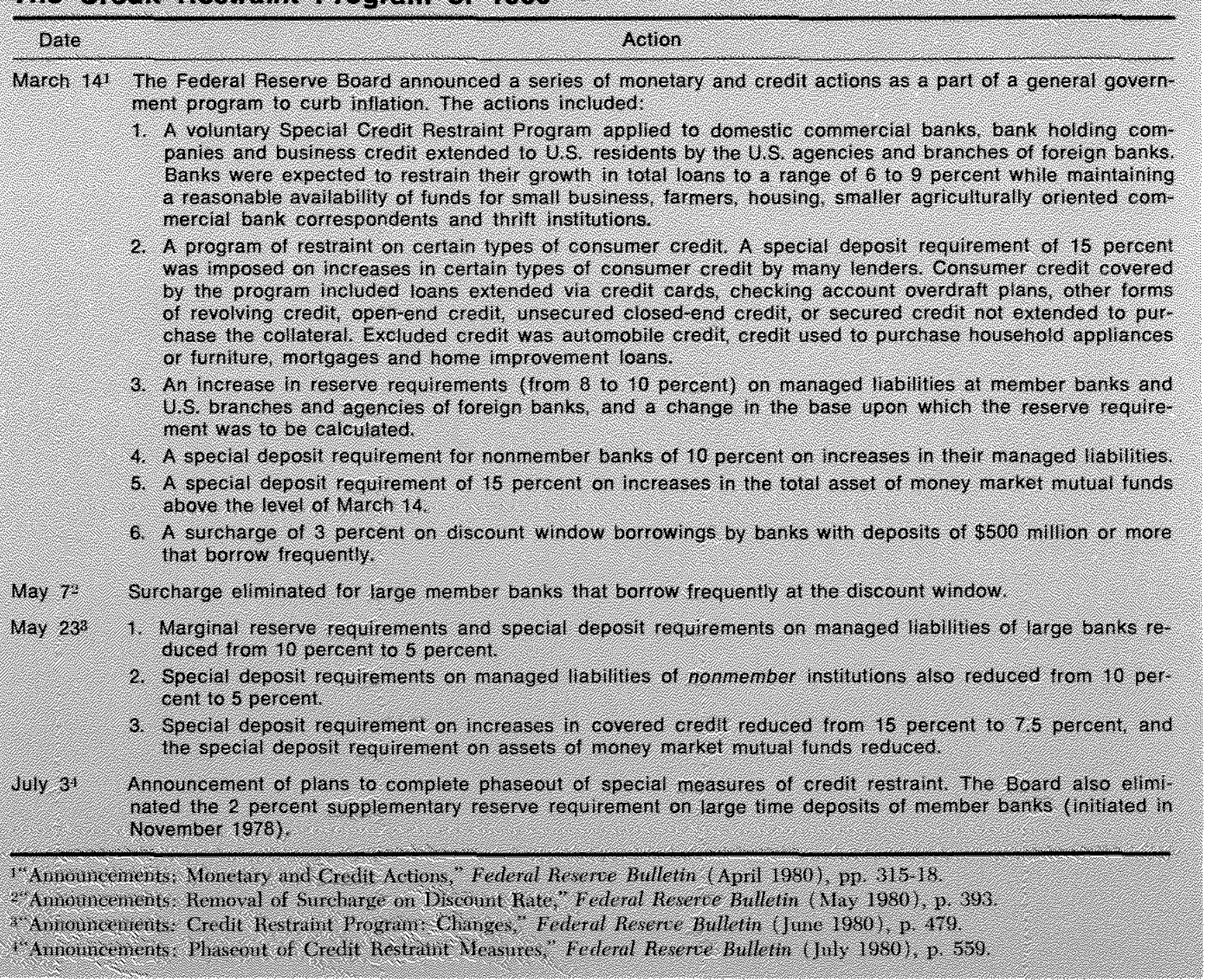

changing rapidly would have been consistent with the sentiment expressed at Committee meetings. At the meeting on April 22, the Committee expressed concern that the objectives of Federal Reserve policy might be misinterpreted if interest rates were falling rapidly. (See the appendix for summaries of discassion at Committee meetings.) At meetings in September, October and November, several members of the Committee expressed the view that, while favoring reductions in growth of the monetary aggregates, they were concemed about the effects on interest rates if the Federal Reserve pursued an aggressive policy of slowing money growth.

The summary of a Federal Reserve staff study of the new operating procedures recognizes the need for more prompt adjustments of the NBR path relative to the TR path or the discount rate than those implemented in 1980 to promote closer control of money in the short run.

Evidence of the past year suggests that during an intermeeting period relatively prompt downward (or upward) adjustments in the original nonborrowed reserve path may be needed in an effort to offset, over time, increased (or decreased) demand for borrowing when money is strengthening (or weakening) relative to target. As an alternative, more prompt upward (or downward) adjustments in the discount rate would tend to discourage (or encourage) borrowing over time. . . . These adjustments min the risk of increasing the volatility of short-run interest rate movements in view of the transitory fuctuations often experienced in short-run money demand. 
However, they could also dampen the amplitude of longer-term swings of interest rates by more promptly leading to adjustments by banks that bring money growth back toward path. ${ }^{20}$

In the February 1981 Monetary Policy Report to Congress, the Federal Reserve also stated the need for more prompt adjustments of NBR paths or the discount rate when TR are projected to deviate from path, in order to achieve better monetary control. ${ }^{21}$

\section{CONCLUSIONS}

Over the year 1980 , the Federal Reserve achieved a small reduction in the trend rate of money growth relative to recent years. Growth rates of $\mathrm{M} 1 \mathrm{~B}$ and $\mathrm{M} 2$, however, exceeded their annual target ranges. Thus, the Federal Reserve did not achieve the degree of deceleration in money growth that it announced as its objective for the year.

Money growth was highly variable during the year, falling below the annual target range during April through July, and rising above the annual range in September through part of December. Until the fall of 1980, the short-term objectives of the Committee were either within the annual target range, or consistent with returning money growth to the annual target

20Stephen H. Axilrod, "Overview of Findings and Evaluation," New Monetary Control Procedures, vol. I, pp. A23-24.

:Monetary Policy Report to Congress (Board of Covernors of the Federal Reserve System, February 25, 1981), pp. 32-33. range. In the fall, however, the Committee voted for the growth of MIB to exceed the top of the annual range, in recognition of a larger than anticipated shift of savings deposits into ATS accounts and concern for the effects of a more restrictive policy on short-term interest rates. Thus, the fact that money growth for the year exceeded the top of the annual target range reflects decisions of the Committee in weighing objectives for monetary control, adjustments to annual money targets for growth of ATS/NOW accounts, and concern about volatility in interest rates.

The record of policy actions under the reserve targeting procedure reflects additional dimensions of monetary policy decisions in 1980. The largest deviations of money growth from the Committee's shortterm objectives occurred when the Federal Reserve failed to take the type of actions that the reserve targeting procedure indicated as appropriate to keep money growth near the short-term objectives. Experience with the reserve targeting procedure does not support the view that fluctuations of the money supply in 1980 reflect problems with monetary control that are basic to the operating procedure. The Federal Reserve has indicated that better short-term control of money growth, using the current procedure, requires more prompt adjustment of the NBR path relative to the TR path, or more prompt adjustment of the discount rate. Thus, short-term monetary control may be improved under the reserve targeting procedure in 1981 and in future years. 


\section{Appendix: Summary of Discussion at Committee Meetings}

\section{January 8-9 Meeting}

Staff projections suggested that a contraction in real GNP would develop in the first quarter of 1980. Price increases were projected to accelerate in the early part of the year, due mainly to substantial in creases in energy prices. Since the previous meeting, interest rates had fluctuated over a wide range, but rates were, nevertheless, less volatile than during the period just after October 6,1979 , when the Federal Reserve announced changes in its monetary policy operating procedures. ${ }^{2}$ On balance, interest rates had declined slightly since the Committee's last meeting.

The Committee specified growth for the first quarter of 1980 at an annual rate of between 4 and 5 percent for $\mathrm{M} 1$ and 7 percent for M2. The federal funds constraint of 11.50 percent to 15.50 percent originally adopted at the October 6, 1979, meeting was kept intact.

\section{February 45 Meeting}

Staff projections continued to suggest that real growth would contract moderately in the period ahead, and that inflation would continue to be rapid due to increases in energy costs. International tensions (in particular, the Russian invasion of Afghanistan) were adding a major degree of uncertainty in projecting output and prices. Most members thought that a moderate contraction in real output was likely in 1980 . Over the intermeeting period, long-term interest rates had risen about one percentage point.

At this meeting, both short-term and long-term ranges for the aggregates were specified in terms

\footnotetext{
Note: Citations to "Record of Policy Actions of the Federal Open Market Committee" of meetings in 1980 are referred to as "Record," in various issues of the Federal Reserve Bulletin. Money growth rates referred to in this appendix are taken from the pullished minutes of the Commitlee's meetings for 1980 and therefore, may not correspond to more tecent benohmark revisions. The data refect information available to the Comnittee at the time of the meetings.

1"Record" (March 1980), pp. 231-36.

"For a discassion of the period of October 6,1979 , to the end of 1980 and the announcement of the new operating procedures, see Richard W. Lang, "The FOMC in 1979: "Introducing Reserve Targeting," this Review (March 1979), pp. 2-24.

3."Record" (April 1980), pp. 325-32.
}

of the newly defined aggregates. Consequently, the staff of the Open Market Desk now had to formulate intermeeting paths of total and nonborrowed reserves consistent with the Committee's short-run objectives for the new aggregates.

The Committee adopted short-term objectives of 4.5 percent and 5 percent for $\mathrm{M} 1 \mathrm{~A}$ and $\mathrm{M} 1 \mathrm{~B}$, respectively. Several members dissented from these actions because they felt interest rates were not exerting enough restraint and that credit was readily available (see table 2 in text).

During the period between the February $4-5$ meeting and the next scheduled meeting in mid-March, two conference calls among Committee members were held to discuss the federal funds rate constraint of 11.50 to 15.50 percent that had been in place since October 6,1979 . The federal funds rate had risen to almost 15 percent after mid-February, and member bank borrowings had increased as the spread between the federal funds rate and the discount rate widened. Inooming data also suggested that M1A and M1B were growing at rapid rates in February. The Committee voted on February 22 to temporarily raise the upper end of the federal funds rate range to 16.50 percent until the situation could be reassessed. The range was further widened to $11.50-18$ percent in a telephone conference of March 7. The "Record" of that meeting states:

On March 6 the federal funds generally traded around 17 percent, despite sizable reserve-supplying operations by the System, and the Manager advised that in his opinion additional leeway above the existing upper limit of 16.50 percent was needed for operational flexibility in meeting reserve objectives. ${ }^{4}$

\section{March 18 Meoting}

On March 14, President Carter amnounced a series of monetary and credit control actions in accordance with the legal authority granted to the President under the Credit Control Act of 1969. The Board of Governors imposed reserve requirements and special deposit requirements on certain types of consumer credit and managed liabilities of commercial banks,

IIbic., p. 332.

$5^{\text {st }}$ Record" (May 1980), pp. 399-406. 
a surcharge of 3 percent on frequent borrowers from the discount window, a special deposit requirement on money market funds, and a voluntary restraint program for the growth of total loans of commercial banks (see table 3 in text for a chronological summary of these actions). This program was later viewed by the Committee as having played a greater role than had been anticipated by affecting the demand for credit and the flow of funds between financial institutions. ${ }^{6}$

Information available at this meeting indicated that real output was continuing to grow in the first quarter. In light of the credit control package announced just a few days before the meeting, however, Committee members continued to stress the unusual degree of uncertainty which affected forecasts of the economy. In its discussion of the near term, the Committee noted that the growth of M1A and M1B over the first two months of the year had exceeded growth rates that were considered consistent with objectives established for the December to March period. Most members favored extending by one quarter the short-term growth rates adopted for the first quarter. There was some sentiment for seeking even slower rates of money growth over the first half of the year to underscore support for the new anti-inflation program.

Members differed in their views regarding the range for the federal funds rate to be adopted for the short-run directive. Since the conference calls during the previous intermeeting period had resulted in changes of the upper limit, the range had been widened from 4 to 6.50 percentage points (from 11.5015.50 percent to $11.50-18$ percent), Some members sought to retain the widened range, while others wanted to restore a 4 percentage-point band. The Committee adopted a range of 13-20 percent, noting that procedures had been established for changing ranges between meetings when such changes seemed appropriate to the Committee.

\section{April 22 Meeting ${ }^{7}$}

Although it was known that real gross national product had grown in the first quarter at about a 1 percent annual rate, information available at this meeting suggested that economic activity had begun to decline near the end of that period and that economic activity would continue to decline for

\footnotetext{
"Monetary Policy Report to Congress," Federal Reserve Bulletin (March 1981), pp. 198-99.

7"Record" (June 1980), pp. $484-89$.
}

several quarters. Price indices were rising at about a 12 percent annual rate in the first quarter. Interest rates had declined considerably during the intermeeting period, after reaching new highs in late March and early April. The prime rate reached 20 percent, but had fallen slightly from that level by the time of the meeting. In March M1A and M1B declined at annual rates of 3.5 percent and 2 percent, respectively, after expanding at rates of 12 percent in February.

Most members of the Committee favored retaining the short-run objectives for money growth adopted at the prior meeting. Some members, however, were concerned that further declines in interest rates might be misinterpreted by market participants as an "easing" of monetary policy,

It was observed that a significant decline in interest rates, if that were to occur in coming weeks, should be regarded as a consequence of the Committee's continuing emphasis on its announced objectives for achieving limited monetary growth and not as a shift toward a stimulative policy. The Committee's monetary objectives should be perceived as fully consistent with a moderation of inflationary forces over time as well as with resistance to recessionary tendencies in the short run.8

In light of the outlook for a lower federal funds rate in the weeks immediately ahead, the Committee lowered the upper limit of the federal funds rate range from 20 percent to 19 percent, but did not change the lower bound of 13 percent. During a telephone conference call on May 6 , the Committee reduced the lower limit of the range for the federal funds rate to 10.50 percent.

\section{May 20 Meeting"}

Evidence accumulated since the last meeting indicated that economic output in the second quarter would decline markedly. In foreign exchange markets, the dollar had declined over most of the previous four weeks; the trade-weighted value of the dollar had fallen about 3.5 percent since the Committee's last meeting.

All of the major monetary aggregates had declined in April, with M1A and M1B declining at annual rates of 18.5 percent and 14.5 percent, respectively, while M2 fell at a 3 percent annual rate. These aggregates fell to levels well below the paths established

\footnotetext{
8 Ibid., p. 487.

"Record" (July 1980), pp. 565-70.
} 
earlier by the Committee. These declines were also accompanied by major declines in both short-term and long-tem interest rates.

The Committee adopted an approach of gradual return to the monetary growth paths consistent with the year's annual targets. The Committee directed perations to achieve growth of $\mathrm{MIA}, \mathrm{MIB}$, and M2 over May and June at annual rates of 7 to 7.5 percent, 7.5 to 8 percent, and about 8 percent, respectively. There were differing views, however, on how agrressively these objectives for the growth of the monetary aggregates should be pursued it the federal funds rate decined sharply.

Concern was expressed that a more aggressive approich would leat to such sharp declines in the federal funds rate and other short-term interest rates in the period immediately ahead that there conld be a perverse impact on long-tem interest rates by exacerbating inlationary expectations, and there could also be strong adverse elfects on the value of the dollar in foreign exchange markets. Moreover, ag. gressive efforts to promote monetary growth might have to be reversed before long, perhaps leading to significant increases in interest rates in a period of substantial weakness in the economy. The possibility was also suggested that the demand for money had shifted downward once again, so that vigorous efforts in the short rum to bring monetary growth into line with the Committee's longer-run objectives could result in excessive creation of money, ${ }^{10}$

\section{July 9 Meeting and Mid-Year Review ${ }^{11}$}

The Committee noted that the growth of M1A and $M 1 B$ had accelerated in June to annual rates of 13.8 percent and 16.8 percent, respectively, following little change in May and sharp contraction in April. The growth of $\mathrm{M} 2$ also accelerated to a 17.3 percent annual rate in June, up from a rate of 8.8 percent in May and a small decline in April. Although market interest rates declined considerably in late May and the first half of June, market rates were again beginning to rise.

Staff projections of the economy indicated that the decline in GNP for the second quarter was larger than previously anticipated. Declines in real growth were expected to continue throughout the end of the year, and a recovery was forecast to begin at the beginning of 1981.

The Committee agreed that open market operations for the third quarter should be geared to

IOlbiel, pp. 567-68.

11"Record" (September 1980), pp. 747-54 and "Monetary Policy Report to Congress," Federal Reserve Bulletin (July 1980), pp. $531-42$. achieving growth rates of M1A, M1B, and M2 at anmual rates of about 7 percent, 8 percent and 8 percent, respectively. However, in light of the shortfall in money growth over the first half of the year, the Conmittee would accept faster growth. It was noted at this time that growth of the narrow aggregates might fall near the lower bounds of their respective annual ranges.

In July of each year, the Committee must review for Congress its monetary growth ranges for the year, and provide a preliminary indication of its ranges for the next year. At its July 9 meeting, the Committee reviewed the annual ranges adopted at its February meeting, and analyzed the growth of the monetary aggregates over the first half of the year. The expansion of M1A and M1B over the first two quarters had fallen substantially below the long-run growth paths established by the Committee in February. The growth of $\mathrm{M} 2$, on the other hand, was stronger and by mid-year was near the midpoint of its range.

The Committee examined annual targets for the growth of the monetary aggregates in terms of the relative growth tates of $\mathrm{MIA}$ and $\mathrm{MlB}$ (as affected by the shift into NOW and ATS accounts), and concluded that "in view of recent evidence of a preference for interest-bearing transactions accounts over demand deposits that was greater than anticipated, it appeared likely that M1B would grow somewhat faster relative to MLA than had been projected earlier in the year." 12 There was general agreement, however, that the growth of these accounts was not "large enough to justify 'fine-tuning' the growth ranges at the expense of causing public confusion about the meaning of the adjustments." 13 The Committee voted to retain the targets for 1950 as adopted at its February meeting. In reaffirming these ranges, it was recognized that the growth rates of $\mathrm{M} 1 \mathrm{~A}$ and $\mathrm{M} 1 \mathrm{~B}$ might fall below the midpoints of their ranges for the year.

In its discussion of growth ranges for 1981, the Committee agreed that further reduction in money growth from the ranges established for 1990 would be appropriate. Committee members disagreed, however, about specific objectives for the growth of the aggregates in 1981, because they expected institutional changes resulting from the Monetary Control Act of 1980 (MCA) to bler the meaning of the narrow aggregates in 1981:

12"Record" (September 1980), p. 750 .

13ribid. 
In particular, relationships among the aggregates will be affected by introduction of NOW accounts on a nationwide basis as of December 31,1980 , as authorized by that act. During 1981, shifts of funds from demand deposits to NOW accounts are likely to be sabstantial, and will retard the growth of M1A. At the same time, transfers from savings deposits and other interest-bearing assets to NOW accounts will enhance the growth of M1B. To the extent that funds are shifted into NOW accounts from other deposit components of M2 and M3, growth of these aggregates will be unaffected. ${ }^{14}$

The Committee decided not to announce precise target ranges for 1981 due to the uncertainty surrounding the possible impact of the MCA on the relationship among the aggregates. After monetary oversight hearings before the Senate and House banking committees, however, the Committee later that month announced more specific objectives: ranges for the growth of M1A, M1B and M2 for 1981 would be reduced "on the order of $1 / 2$ percentage point from the ranges adopted for 1980 , abstracting from institutional influences affecting the behavior of the aggregates."15 (Italics added.)

\section{August 12 Meeting $^{16}$}

Early in the intermeeting period, the monetary aggregates grew slightly faster than the rates specified by the Committee for the period from June to September. At its July meeting, the Committee had agreed that moderately faster growth than the shortrun targets would be acceptable. Later in the intermeeting period, both M1A and M1B appeared to be growing considerably faster than their specified rates, The growth rates of $\mathrm{M} 1 \mathrm{~A}$ and $\mathrm{M} 1 \mathrm{~B}$ from the fourth quarter of 1979 through July, however, were still below rates consistent with the Committee's ranges for the year. Market interest rates had risen during the intermeeting period; short-term interest rates increased about 50 basis points and long-term rates about 75 basis points. The staff projected that real GNP would continue to decline through the end of the year, but not as rapidly as the preliminary estimate of a reduction in real GNP at a 9.1 percent annual rate for the second quarter.

In its deliberations on the short-run aggregate directive, the Committee took note of a staff analysis which suggested that, if third quarter growth continued for $\mathrm{M} 1 \mathrm{~B}$, that aggregate would be near the

14 Ibid.

15lbid., p. 753 .

$16^{\prime \prime}$ Record" (October 1980), pp. 835-39. midpoint of its amual range by the fourth quarter; the growth of M2 would be at the upper end of its range. In July M1A and M1B grew at annual rates of about 7.5 percent and 10.8 percent, respectively, and M2 grew at a 17 percent rate.

Some members expressed concern that a short-run target for M1A appreciably below the 7 percent rate voted at the prior meeting would catse further increases in interest rates at a time when the longerrun targets did not clearly suggest the need for re duced growth in the monetary aggregates. ${ }^{17}$ The Committee voted for a slightly reduced rate of growth for M1A (6.5 percent) over the third quarter and higher rates for $\mathrm{M} 1 \mathrm{~B}$ and $\mathrm{M} 2$ ( 9 percent and 12 percent, respectively). A federal funds rate range of 8 to 14 percent was adopted.

\section{September 16 Meeting $^{18}$}

Staff projections reviewed at this meeting suggested that the economy would recover by the end of the year. Declines in real GNP for the third quarter were expected to be less pronounced than had been thought just a month earlier. The Committee, for the most part, shared the outlook that the economy was somewhat stronger than had been anticipated previously, and some members believed the economy was stronger than the staff was projecting. There was broad agreement, though, on the staff estimate of only modest gains in the economy in 1981.

The growth of M1A and M1B accelerated in August to annual rates of about 19.5 percent and 22 percent, respectively, and M2 grew at a 14.3 percent rate. It was then evident that policy over the period ahead should be directed toward a deceleration in money growth in order to achieve the Committee's objectives for the year. For the period from the fourth quarter of 1979 through August, the growth of MlA was in the lower half of the Committee's longrun range, but $\mathrm{MlB}$ was in the upper half of its range, and M2 was somewhat above the upper limit of its range. Market interest rates exhibited wide fluctuations in the intermeeting period, but on balance had risen since the last meeting.

Although there was broad agreement that monetary expansion should be reduced in the period ahead, views differed concerning the specific shortrun growth objectives to be adopted. One group

17Ibid., p. 838.

1s"Record" (November 1980), pp. 883-87. 
favored growth rates on the lower side of the ranges discussed at the meeting, emphasizing "the need for a policy posture that would minimize any risk of exacerbating inflationary forces in the economy or worsening inflationary expectations." 19 Another group favored more rapid rates of money growth (but less rapid than the July-September period) and appeared to be concerned about a recent rise in interest rates, since "these increases might well begin to reduce money and credit demands over the months ahead, that economic recovery was in its very early stages, and that some sectors such as housing were especially sensitive to emerging credit conditions." ${ }^{2}$

A middle course was adopted by the Committee - one calling for the growth of MIA, MIB and M2 over the August-December period at annual rates of about 4 percent, 6.5 percent and 8.5 percent, respectively.

\section{October 21 Meeting}

Preliminary data available at this meeting indicated that real GNP had expanded in the third quarter at an amual rate of 1 percent. Staff projections suggested that the third quarter marked the beginning of a recovery. Prices continued to rise at about a 10.5 percent annual rate.

Early in the intermeeting period, data indicated that the monetary aggregates were continuing to grow at rates faster than those consistent with the Committee's objectives for the August-December period. Short-term interest xates also rose over the intermeeting period; long-term rates, however, changed little on balance. In the days just prior to the October 21 meeting, the federal funds rate was trading in the area of 12.50 to 13 percent, compared with 10.50 to 11 percent just before the last Committee meeting on September 16.

In its discussion of policy for the near term, all of the voting members favored the pursuit of a sharp reduction in monetary expansion over the final months of 1980 in order to reach their long run money growth objectives for the year. Nevertheless, as in the previous meeting, members differed in their views about the exact short-run policy directive to be adopted. One group favored growth objectives for the final months of the year consistent with the growth rates adopted at the Committee's meeting in September;

19Ibid., p. 886 .

rolbid.

21"Record" (December 1980), pp. 968-73. that is, they would adjust for the overshoot in September in order to achieve the long-run objective of the Committee for the year.

Another group placed less significance on specifying short-run targets precisely consistent with the AugustDecember objectives and cited the volatility of shortrun money growth data.

Other members, while also seeking sharply reduced growth rates of the aggregates in the months ahead, attached less significance to targets precisely consistent with the Angust-to-December objectives adopted a month earlier, in light of the inherent volatility of the data in the short run. Committee actions affected the money supply only with some lag, and given actions already in place and the uncertainties of the economic outlook, the possibility could not be excluded that very ambitious short-run objectives with respect to restraint could generate undesirable instability in both interest rates and the money supply over a somewhat longer period and thus be counter to the Committee's more fundamental goals. ${ }^{22}$

The Committee adopted a short-run directive that attempted to reconcile the competing views expressed by various groups. The Committee agreed to target paths for M1A, M1B and M2 over the SeptemberDecember period at annual rates of about 2.5 percent, 5 percent and 7.25 percent, respectively. It was noted that M1B could exceed the upper bound of its long-run range if increases over the months ahead equaled or exceeded the adopted numerical specifications.

\section{Nowember 18 Meeting $^{23}$}

Data available to the Committee at this meeting suggested that economic activity was continuing to expand in the fourth quarter. Short-term interest rates rose 1.75 to 3 percentage points over the intermeeting period, while long-term rates increased about 75 basis points. Staff projections suggested that growth of real output in the fourth quarter would be slightly greater than the 1 percent growth rate in real GNP for the third quarter. The staff's projections continued to predict little growth over the next few quarters.

M1A and MIB grew at about 9 and 11 percent annual rates, respectively, in October and were substantially above the short-rum objectives voted at the last Commitee meeting. The growth of M2 accelerated slightly to a 9 percent rate. Through October, M1A was in the upper part of the Committee's annual

\footnotetext{
${ }^{22}$ Ibid., pp. 971-72.

23 "Record" (January 1981), pp. 27-33.
} 
range; M1B and M2, however, were above their annual ranges.

Most members favored reaffirming the short-rum objectives for the monetary aggregates over September-December that were voted at the last meeting, which would require sharp declines in the aggregates during the remainder of the year. Members had differing views, however, on how aggressively to pursue these objectives.

While favoring shapply reduced growth of the monetary aggregates in the period immedately ahead, a number of members expressed concern abotit inadvertently contributing to the volatility of interest rates, because of the implications of such volatility for economic activity, for inflationary psychology, and for the functioning of firancial markets. Specifically, a substantial reduction in the provision of nomborrowed reserves or other measures in a highly aggressive pursuit of the short-run monetary growth rates being contemplated might lead promptly to further increases in interest rates, which were probably already constraining the business recovery and slowing monetary growth. Subsequent declines in rates might be unduly large, and if monetary growth accelerated again in lagged response, inflationary expectations could well be heightened.

Shortly after the November meeting, data indicated that the monetary aggregates were growing considerably faster than the rates consistent with the Committee's shortrun objectives. In addition, the federal funds rate was just above 17 percent, the upper end of the range specified at the November meeting. During a telephone conference on November 26 , the Committee raised the upper limit of the federal funds range to 18 percent. The federal funds rate continued to rise, however, and by the morning of December 5 was above 18 percent. On December 5 the Committee temporarily suspended the upper bound of the range, and on December 12 suspended the range until the next scheduled meeting.

\section{Decenber 18-19 Mecting ${ }^{2 \pi}$}

Information analyzed at this meeting suggested that real economic growth would expand more than in the previous quarter. Prices continued to rise at about a 10.5 percent annual rate. The trade-weighted value of the dollar against major foreign currencies had risen about 2.5 percent since the Committee's mid-November meeting. Staff projections suggested that real output growth, after some accelerated

${ }^{2} 4$ Ibid, p. 30 .

$25^{\prime \prime R e c o r d " ~(F e b r u a r y ~ 1981), ~ p p . ~ 149-54 . ~}$ growth in the current quarter, would decline in the first half of 1981. Slow economic growth during the remaining portion of 1981 was also projected. The rise in prices over this period was projected to remain rapid, but not as rapid as in 1980 .

Growth of M1A and MIB moderated in November but was still above the Committee's objectives for the period from September to December. The expansion of $\mathrm{M} 2$ and $\mathrm{M} 3 \mathrm{in}$ November continued to accelerate. In early December, however, $M \perp A$ and MIB were actually falling. As measured from the fourth quarter of 1979 through November, growth of M1A was in the upper part of its long-rum range; $\mathrm{M} 1 \mathrm{~B}$ and $\mathrm{M} 2$, however, exceeded their respective long-run ranges.

The Conmittee, in its consideration of a short-tem policy directive, reviewed the tentative long-run ranges for 1981 adopted in July. It was agreed that money growth over the first quarter of 1981 should be consistent with the tentative ranges adopted in July for 1981: targeted growth rates for the aggregates were intended to represent a 0.5 percentage point reduction in the ranges adopted for 1980 , ab. stracting from effects of deposit shifts connected with the introduction of NOW accounts on a nationwide basis in Jannary 1981.

In the short-run the Committee sceks behavior of reserve atgeregates associated with growth of $\mathrm{MlA}$, $\mathrm{M} 1 \mathrm{~B}$, and $\mathrm{N2}$ over the first quarter along a path consistent with the ranges for growth in 1.981 contemplated earlier, which will be reviewed in Folmuary 1981. Those ranges, abstracting from the effects of deposit shifts connected with the introduction of NOW accounts on a nationwide hasis, mply growth in these arggregates centered on 4.25 percent, 4.75 pereert, and 7 percent respectively. It is recognized that the introduction of NOW and ATS arcounts nationwide at the begimning of 1981 is likely to widen the discrepancy between growth in M1A and MIB to an extent that canot now be accumately estimated, and operational reserve paths will bo developed in light of evaluation of those differences as they emerge.20

In other words, the Committee's task of monitoring and selecting money growth rates over the short-min would have to rely on staff estimates of how these institutional changes were affecting growth of the aggregates. In turn, the Manager of the Open Market Desk would have to translate these short-term paths adopted by "abstracting from the effects of deposit shifts" into reserve paths consistent with these growth rates.

20 Ibiti., p. 154. 